\title{
Sinop Karasu Çayı fizikokimyasal özellikleri ve mikrobiyolojik kirliliğinin araştırılması
}

\section{Assessment of Sinop Karasu Stream's physicochemical properties and microbiological pollution}

\author{
Ayşe GÜNDOĞDU1 ${ }^{\mathscr{P}}$ (D), Uğur ÇARLI ${ }^{2}$ iD \\ ${ }^{1}$ Sinop University, Faculty of Fisheries, Department of Hydrobiology, Sinop, Turkey. \\ ${ }^{2}$ Sinop University, Scientific and Technological Researches Center, Sinop, Turkey.
}

MAKALE BILGISI / ARTICLE INFO

Makale tarihçesi / Article history:

DOI: $10.37908 / \mathrm{mkutbd} .690179$

Geliş tarihi /Received:17.02.2020

Kabul tarihi/Accepted:29.06.2020

\section{Keywords:}

Coliform, creek, river, pollution, water quality, Karasu Stream, Black Sea.

\footnotetext{
Corresponding author: Ayşe GÜNDOĞDU

$\triangle$ : aysegundog57@sinop.edu.tr
}

\section{ÖZET / A BSTRACT}

Atıf / Citation: Gündoğdu A, Çarlı U (2020) Sinop Karasu Çayı Fizikokimyasal Özellikleri ve Mikrobiyolojik Kirliliğinin Araştırılması. MKU. Tar. Bil. Derg. 25(2) : 284-299. DOI: 10.37908/mkutbd.690179

\section{GiRiş}

Su, tüm canlı organizmalar için gerekli olan spesifik, doğal ve hem tüketilebilir hem de yenilenebilir bir kaynaktır. Çünkü belirli bir yerde ve zamanda tüketildiğinde veya çok kirletildiğinde, miktarı ve kalitesi uygun koşullar altında geri kazanılabilir (Bogdal ve ark., 2016). Bugün, dünyadaki tüm su kaynakları kirlilik ve yok olma riskiyle karşı karşıyadır. Bu durum turizm faaliyetleri, evsel ve endüstriyel atıklar ile 
ilişkilendirilebilir. Ayrıca, küresel ısınmanın getirdiği iklim değişiklikleri ve kuraklık nedenler arasında gösterilebilir. Bu olumsuz faktörlerin sonucu olarak, su kaynakları hızla azalmaktadır (Küçük, 2007). Bu nedenle, uygun su durumunun korunması ve sürdürülebilirliğin sağlanması giderek önem kazanmaktadır.

Yeryüzü sularının kalitesi doğal çevre ve insanlar için oldukça önemlidir ve suların spesifik fiziksel, biyolojik, kimyasal ve mikrobiyolojik özelliklerinin iyi bilinmesi gerekmektedir (Kanownik ve Rajda, 2011; Napieralska ve Gołdyn, 2013). Ayrıca, yüzey ve yeraltı suyu yapısı için; ayrışma, hidrolizlenme, çözünme, adsorpsiyon, sedimantasyon, iyon değişimi, indirgeme ve oksidasyon prosesleri gibi kimyasal ve biyokimyasal reaksiyonlar önemli kontrol faktörleridir (Wu ve ark., 2014). $\mathrm{CO}_{2}$, ORP, $\mathrm{PH}$, toplam askıda katı madde, alkalinite ve hidrojen sülfit, organik madde, amonyum ve nitrat gibi fizikokimyasal parametrelerin değerlendirilmesi, genellikle su kalitesinin yönetmelik ilkelerini belirlemede ve sınıflandırılmasında esas alınmaktadır (Anonymous, 1997a; Abreu-Acosta ve Vera 2011).

Sudaki indikatör mikroorganizmaların varlığı, suyun insanlardan veya başka bir sıcak kanlı hayvandan gelen fekal malzeme ile kontamine olduğunu açıklamaktadır. $\mathrm{Bu}$ tür bir kontaminasyon, hayvanların bağırsak sisteminde meydana gelen herhangi bir normal flora veya patojenik mikroorganizmaların da oluşturulabileceği anlamına gelmektedir (Al-Bahry ve ark., 2009; Hamzah ve ark., 2011; Mostafa ve ark., 2013; Singh ve ark., 2019). Yüzey sularındaki virüslerin yüksek yayılımı, kronik bir kirlilik probleminin ve insanlar için potansiyel risk oluşabileceğinin göstergesidir (Lipp ve ark., 2001). İndikatör mikroorganizmalar, koliform bakterilerdir ve F. koliform ve fekal olmayan koliform olarak ikiye ayrılır. Dışkı tipi, insan bağırsak sisteminde ve diğer sıcak kanlı hayvanlarda bulunan normal flora olan Escherichia coli türüdür. Fekal olmayan tip, doğada yaygın olarak bulunan ve bazen sıcak kanlı organizmaların bağırsak sisteminde bulunan Enterobacter aerojenleri içerir (Anonymous, 1997a; AlBahry ve ark., 2009; Abreu-Acosta ve Vera, 2011). Kirli su ortamında bulunan bağırsak bakterileri, göçmen balık türlerini, hareketli balık türlerini ve yerleşik kabukluları kirletebilirler. Çift kabuklular filtre besleyicilerdir, kanalizasyon kirliliğinden etkilenen sularda patojenik mikroorganizmaları dokularında yüksek sayıda konsantre edebilirler (Ward ve Hackney, 1991; Kilinc ve Besler, 2014).

Su ekosisteminde bulunan mikroorganizmalar ya çeşitli yollarla suya karıştırılır ya da çevresel koşullarla oluşurlar. Mikroorganizmalar atmosferden ve topraktan doğal sulara gelebilir ve aynı zamanda endüstriyel ve evsel atık kökenli olabilirler (Elmanama ve ark., 2006; Acehan, 2007; Elmacı ve ark., 2008). Bunlar arasına, Spillillum, Pseudomonas, Chromobacter, Achromobacter, Vibrio, Micrococcus ve Sarcina'nın çürükcül üyeleri Bacillus, Enterobacteriacea ve Streptomyces gibi, Esherichia coli, Salmonella ve Vibrio (virgül), Streptococcus faecalens, Clostridium perfiringens gibi patojenler dahil edilebilir. Bu tür mikroorganizmalar su kaynaklarının biyokimyasal yapısında değişikliklerin yanı sıra zararlı, tehlikeli ve hastalığa neden olabilirler (Aksu, 2004; Fakir, 2012; Ayaz, 2015). Genellikle toplam koliformlar, fekal koliformlar ve fekal streptokoklar su kalitesi çalışmalarında kullanılan en yaygın indikatör mikroorganizmalardır (Hamzah ve ark., 2011). Escherichia cinsinin üyeleri toplam koliformların \% 60'ından fazlasını ve fekal koliformların \% 90'ından fazlasını içerirler. En önemli koliform bakterilerden biri Escherichia coli'dir. Bu türün çeşitli türleri fırsatçı patojenlerdir ve hastalık nedeni olabilirler (Berber ve Avşar, 2014). Kanalizasyon bakterilerinin yüksek konsantrasyonları, kanalizasyonun çevreye nüfuz etmesi durumunda insan sağlığı için potansiyel bir tehdittir. Bağırsak bakterileri olarak, tifoya neden olanlar da dahil olmak üzere gram negatif bakteriler (Salmonella) özel patojenik özellik sergilemektedirler (Hagendorf ve ark., 2000; Sigua ve ark., 2010). Bu mikroorganizmalar ateş, bulantı, kusma, ishal gibi birçok soruna neden olabildiği gibi aynı zamanda ölüm nedeni olabilirler (Salyers ve Whitt, 2012; Augustyn ve ark., 2016).

Doğal sulara özellikle insan ve hayvan dışkılarıyla karışan virüsler ve patojen mikroorganizmalar önemli bir sağlık riski sorunu oluştururlar. Suların hijyenik açıdan kirlenmesinin en önemli nedeni olan virüsler, bakteriler ve diğer hastalık yapıcı organizmalardır. Genellikle hastalıklı veya hastalık taşıyıcı hayvan ve insanların dışkılarından kaynaklanırlar. Bu atıklarla doğrudan temasla veya atıkların karıştığı sulardan dolaylı yollardan bulaşıcı etki ortaya çıkabilir. Rekreasyonel kullanıma açık sularda ve içme suyu temininde mikrobiyolojik olmak üzere her türlü kirletici ile suların kirlenmesi önemli bir sorun oluşturmaktadır (Kolören ve ark., 2011). Fekal indikatör bakteriler, genellikle kendileri zararlı olmasa da, su kütlesindeki varlıkları diğer patojenik mikroorganizmaların olası varlığını gösterebilir (Burres, 2009). E. coli ve Enterococci gibi indikatör bakteriler sadece hafif enfeksiyonlara neden olsa da, bunların varlığı insan sağlığı için tehlike arz etmektedir (Majedul Islam ve ark., 2017). Bu nedenle patojenlerle kirlenmiş sular, çeşitli amaçlarla su kaynağı olarak potansiyel kullanımı sınırlar. 
Çalışmamızın amacı, Karasu Çayı'nın fizikokimyasal özellikleri ile mikrobiyolojik kirlenmeyi oluşturan bileşenlerinin mevsimsel değişimlerinin gözlemlenmesi ve genel olarak hangi bölgelerde ve hangi mevsimde kirliliğe maruz kaldıklarını belirleyerek, bununla ilgili çözüm önerileri getirmektir. Ayrıca, Karasu Çayı́nın yüzey sularındaki $\mathrm{T}$. koliform ve $\mathrm{F}$. koliform bakteri miktarını değerlendirerek, su kalitesinin seçilen fizikokimyasal değişkenleri ile bu sularda test edilen bakteri gruplarının kantitatif oluşumu arasındaki ilişkiyi araştırmaktır.

\section{MATERYAL ve YÖNTEM}

Çalışma Mayıs 2014 - Nisan 2015 tarihleri arasında aylık periyotlar halinde gerçekleştirilmiş olup, sonuçlar mevsimsel olarak hesaplanmıştır. Yerleşim alanlarının ve tarımsal arazilerin yoğun olduğu bölgelerde, özellikle deşarj noktaları dikkate alınarak dört istasyon $(1,2,3$ ve 4) belirlenmiştir. Su örnekleri, nehir boyunca belirlenen istasyonların her birinden; mikrobiyolojik analiz için steril kahverengi cam şişelerle (102 $\mathrm{mL})$ ve fizikokimyasal analizler için mat plastik kaplarla $(2.5 \mathrm{~L})$ toplanmıştır. Alınan tüm numuneler güneş ışığından korunarak en kısa zamanda ve soğuk $\left(4^{\circ} \mathrm{C}\right)$ zincir yardımı ile laboratuvara nakledilmiştir.

\section{Çalışma Alanının Özellikleri}

Karasu Çayı, Karadeniz Bölgesi'ndeki Küre Dağları'ndaki Gündüzlü Ormanlarından doğmaktadır. Güney-kuzey yönünde hareket eden Karasu Çayı, Erfelek ilçesine kadar uzanmakta ve suları Sinop ilinin $8 \mathrm{~km}$ batısındaki Akliman sahilinden Karadeniz'e boşalmaktadır. Çayın uzunluğu yaklaşık $80 \mathrm{~km}$ 'dir ve geniş tabanlı bir vadide hareket etmektedir. Çakçak, Çatak, Hasan, Ramlı, Kınık ve Tasnak dereleri Karasu Çayı'nı beslemektedirler (Çarlı, 2015). Karasu Çayı üzerinde yer alan Tatlıca Şelalesi, Erfelek ilçe sınırları ve Tatlıca Köyü içerisinde yer almaktadır. Vadi boyunca merdiven basamakları şeklinde oluşmuş, irili ufaklı 28 adet şelaleden oluşmuştur (Uzun ve ark, 2005). Sinop ilinin içme suyu arıtma tesisi, suyu Karasu Çayı yönünde bulunan Tatlıca şelalesinden temin etmektedir. Karasu Çayı'nı temsil eden, farklı özelliklere sahip dört istasyon belirlenmiştir. 1.ístasyon (İst.): Karasu Çayı'nın denizle birleştiği bölgedir. Sinop şehir merkezindeki Akliman yerleşim bölgesinde ve bölgenin etkisi altındadır. 2.İst.: Yerleşim alanının arkasında bulunmakta ve Sinop merkez köylerine yakın ve insan faaliyetlerinin yoğun olduğu bölgededir. Ayrıca son zamanlarda Akliman bölgesi turizm açısından gelişmiş ve nüfus yoğunluğu artmıştır. 3.íst.: Sinop ili Ayancık yolu üzerindeki Karasu köprüsünün altındadır. Bu bölge tarım arazilerinin yoğun olduğu ve hastane atıklarının Karasu çayı'na karışma intimalinin olduğu alandadır. 4.ist.: Mertoğlu köyü, Sinop merkezine $10 \mathrm{~km}$ uzaklıktadır. Tarımsal faaliyetlerin yoğun olduğu bir bölgededir. Tarımda kullanılan kimyasalların sulama kanalları ve yağmur suyu ile Karasu Çayı́na ulaşma olasılığı dikkate alınmıştır (Şekil 1).

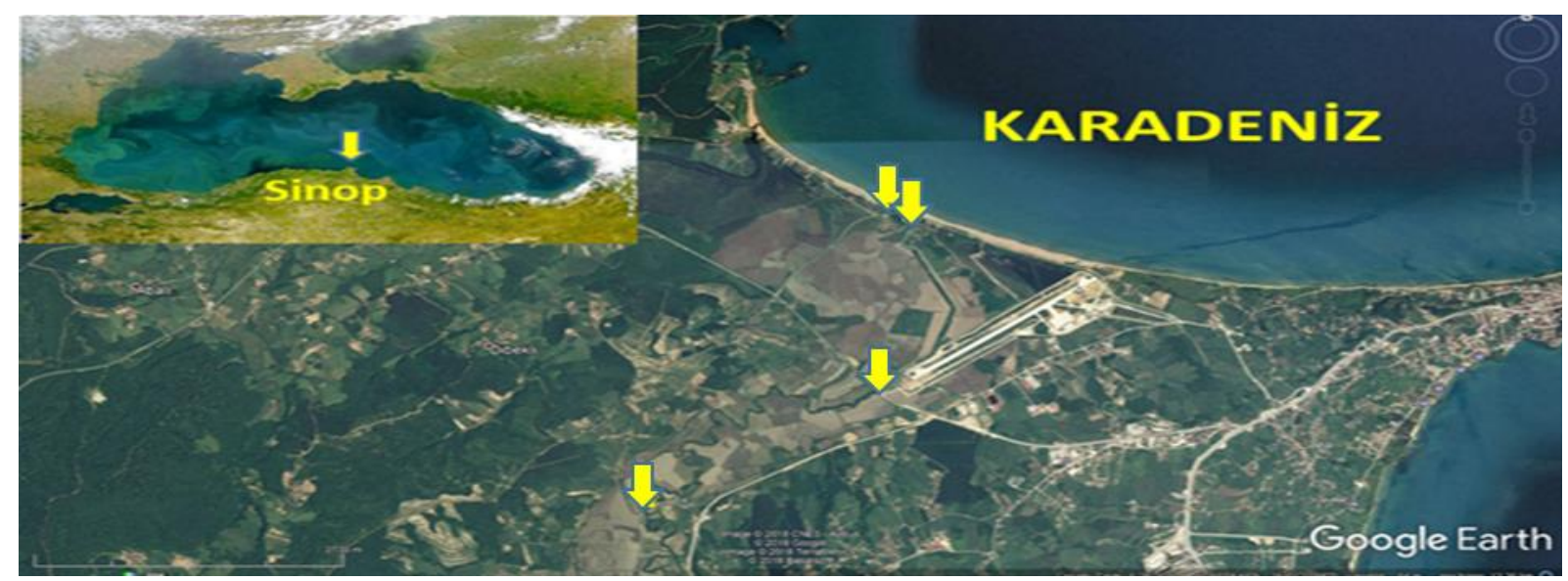

Şekil 1. Karasu Çayı (Sinop) çalışma alanı ve örnekleme istasyonları (1.íst.: $42^{\circ} 02^{\prime} 19.8^{\prime \prime} \mathrm{N}, 35^{\circ} 02^{\prime} 44.1^{\prime \prime} \mathrm{E}$; 2.ist.: $42^{\circ} 01^{\prime} 47.6^{\prime \prime} \mathrm{N}, 35^{\circ} 03^{\prime} 40.9^{\prime \prime E}$; 3.ist.: $42^{\circ} 00^{\prime} 41.1^{\prime \prime} \mathrm{N}, 35^{\circ} 03^{\prime} 29.4^{\prime \prime} \mathrm{E}$; 4 .ist.: $\left.42^{\circ} 00^{\prime} 41.1^{\prime \prime} \mathrm{N}, 35^{\circ} 03^{\prime} 29.4^{\prime \prime E}\right)$.

Figure 1. Karasu Stream (Sinop) study area and sampling stations (1.ist: $42^{\circ} 02^{\prime} 19.8^{\prime \prime} \mathrm{N}, 35^{\circ} 02^{\prime} 44.1^{\prime \prime} \mathrm{E}$; 2. ist: $42^{\circ} 01^{\prime} 47.6^{\prime \prime} \mathrm{N}, 35^{\circ} 03^{\prime} 40.9^{\prime \prime} \mathrm{E}$; 3.ist: $42^{\circ} 00^{\prime} 41.1^{\prime \prime} \mathrm{N}, 35^{\circ} 03^{\prime} 29.4^{\prime \prime} \mathrm{E}$; 4.ist: $42^{\circ} 00^{\prime} 41.1^{\prime \prime} \mathrm{N}, 35^{\circ} 03^{\prime} 29.4^{\prime \prime} \mathrm{E}$ )

\section{Fizikokimyasal Parametreler}

Çalışmada, sıcaklık $\left({ }^{\circ} \mathrm{C}\right)$, karbondioksit $\left(\mathrm{CO}_{2}\right.$, miligram litre $\left.{ }^{-1} ; \mathrm{mg} \mathrm{L}^{-1}\right), \mathrm{pH}$, alkalinite $\left(\mathrm{mg} \mathrm{L}^{-1}\right)$, çözünmüş oksijen
(ÇO, mg L ${ }^{-1}$ ), iletkenlik (mikrosiemens santimetre ${ }^{-1}$ : $\mu \mathrm{s}$ $\mathrm{cm}^{-1}$ ), Oksidasyon-Redüksiyon Potansiyeli (ORP: milivolt; $\mathrm{mV}$ ), klorür (gram litre ${ }^{-1} ; \mathrm{g} \mathrm{L}^{-1}$ ), biyolojik oksijen ihtiyacı 
$\left(\mathrm{BOI}_{5}, \mathrm{mg} \mathrm{L}^{-1}\right)$, amonyum azotu $\left(\mathrm{NH}_{4}{ }^{+}-\mathrm{N}, \mathrm{mg} \mathrm{L}^{-1}\right)$, hidrojen sülfür $\left(\mathrm{H}_{2} \mathrm{~S}, \mathrm{mg} \mathrm{L}^{-1}\right)$, organik madde $\left(\mathrm{OM}, \mathrm{mg} \mathrm{L}^{-1}\right)$, toplam askıda katı madde (TAKM, $\mathrm{mg} \mathrm{L}^{-1}$ ) parametreleri seçilmiştir. Sıcaklık, çO, pH, ORP, iletkenlik ve klorür ölçümleri örnekleme alanlarında YSI marka çok parametreli (Professional Plus model) cihazla yapılmıştır. $\mathrm{BOI}_{5}, \mathrm{NH}_{4}{ }^{+}-\mathrm{N}, \mathrm{H}_{2} \mathrm{~S}$, OM ve TAKM ölçümleri ve analizleri, sular için geçerli olan Standart Yöntemler uygulanarak laboratuvar koşullarında yapılmıştır. $\mathrm{CO}_{2}$ (Bekleme süresi; $\mathrm{Bs}-1$ gün), alkalinite, $\mathrm{BOI}_{5}\left(\mathrm{Bs}-24\right.$ saat; $1-5^{\circ} \mathrm{C}^{\prime} \mathrm{de}$ ) ve $\mathrm{H}_{2} \mathrm{~S}$ (Bs-1 hafta, $1-5^{\circ} \mathrm{C}^{\prime}$ de, alınır alınmaz $2 \mathrm{~mL}$ çinko asetat çözeltisi ilâve edilir, pH ayarlanır) Titrimetrik yöntem, $\mathrm{NH}_{4}{ }^{+}-\mathrm{N}$ (Bs-1 gün, numuneler yerinde filtre edilir) Spektrofotometrik yöntem (RAYLEIGH UV-726), OM (Bs7 gün, pH 1-2'ye ayarlanır) ve TAKM ( Bs- 2 gün, $1-5^{\circ} \mathrm{C}^{\prime} \mathrm{de}$, $\mathrm{pH}$ 3'e ayarlanır) için Gravimetrik yöntem ile belirlenmiştir (APHA, 1999; Egemen ve Sunlu 1996; Anonim 2015b).

\section{Mikrobiyolojik Analizler}

Mikrobiyal analizi için, su numuneleri istasyonlarda steril kaplarda toplanmıştır. Numune kapları, su yüzeyinden 20-30 cm derinliğe kadar baş aşağı batırılmış ve $45^{\circ}$ eğimle doldurulmuş ve buzla soğutulmuş koşullar altında laboratuvara taşınmıştır. Mikrobiyal değerlendirme için toplam (T.) koliform ve fekal (F.) koliform (kob 100-1 $\mathrm{ml}^{-}$ ${ }^{1}$;100 mililitre'deki koloni sayısı) analizi yapılmıştır (Anonim 2015b). Numuneler $100 \mathrm{ml}$ steril numune kaplarına alınarak $10^{-3}$ dilüsyon seyreltmesine inilerek 3 paralel olacak şekilde membran filtrasyon yöntemi ile analiz edilmiştir. Vakum pompası yardımı ile por çapı $0.45 \mu \mathrm{m}$ olan filtrelerden süzülmüş olup, besiyerlerine filtre kağıtları yerleştirilerek uygun sıcaklıklarda inkübasyona tabi tutulmuştur. Çalışmada T. koliform için ENDO Agar ve F. koliform için m-FC Agar nutrient ped sistemleri kullanılmıştır. Filtreleri içeren ortam; $T$. koliform için $37 \pm 0.1^{\circ} \mathrm{C}$ ve $\mathrm{F}$. koliform için $44.5 \pm 0.1^{\circ} \mathrm{C}$ 'de 24 saatlik bekleme süresinin sonunda değerlendirmeye alınmıştır. ENDO Agar üzerinde gelişen koyu kırmızı, metalik yeşil koloniler T. koliform ve $\mathrm{m}$-FC Agar üzerinde gelişen mavi koloniler fekal koliform olarak belirlenmiştir (Halkman, 2005).

\section{istatistiksel Analizler}

$\mathrm{Su}$ kalitesi parametrelerinin istatistiksel analizleri Minitab 18 paket programı ile yapılmıştır. Tüm parametrelerin istasyonlar ve mevsimler arasında farklılık gösterip göstermediğini belirlemek için iki yönlü ANOVA (varyans analizi) testi uygulanmıştır. Anlamlı farklılıkların hangi istasyonlarda ve mevsimlerde olduğunun belirlenmesi amacıyla da "Tukey testi" uygulanmıştır. Ayrıca örneklerin bazı parametre konsantrasyonları arasındaki ilişkileri değerlendirmek için korelasyon matrisleri oluşturulmuştur. Fizikokimyasal parametreler ile koliform bakterileri arasındaki korelasyon katsayıları değerlendirilmiştir.

\section{BULGULAR ve TARTIŞMA}

Karasu Çayı koliform bakterileri ve bazı fizikokimyasal parametreler Çizelge 1-2'te gösterilmiştir. Akarsuyun mikrobiyolojik değerlendirmesinde $T$. koliform ve $F$. koliform bakterilerinin varlığı tespit edilmiştir. T. Koliform'un minimum ve maksimum değerleri 1.ist., 2.ist., 3.ist. ve 4.ist. istasyonlarında sırasıyla 52-882, 37799, 50-689 ve 27-305 kob 100-1 $\mathrm{ml}^{-1}$ olarak bulunmuştur. F. koliformun minimum ve maksimum değerleri ise 1.ist., 2.ist., 3.ist. ve 4.ist. istasyonlarında sirasiyla 47-644, 24-568, 21-649 ve 19-213 kob $100^{-1} \mathrm{ml}^{-1}$ olarak belirlenmiştir. Çalışmada mevsimlerin ve istasyonların $\mathrm{BOI}_{5}, \mathrm{NH}_{4}{ }^{+}-\mathrm{N}, \mathrm{OM}, \mathrm{T}$. koliform ve $\mathrm{F}$. koliform ortalama değerleri arasında istatistiksel olarak anlamlı bir fark $(P<0.05)$ bulunmuştur.

Sıcaklık, $\mathrm{CO}_{2}, \mathrm{pH}$, ÇO ve $\mathrm{H}_{2} \mathrm{~S}$ değerleri mevsimler arası önemli ölçüde farklılık gösterirken $(P<0.05)$, istasyonlar arası farklılık $(P>0.05)$ olmamıştır (Çizelge 1$)$. Ayrıca, iletkenlik, klorür ve askıda katı maddeler hem istasyonlarda hem de mevsimsel olarak istatistiksel

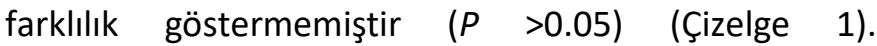
Fizikokimyasal parametreler ile koliform bakteriler arasındaki korelasyon katsayıları $P<0.05, P \leq 0.01$ and $P$ $\leq 0.001$ 'e göre değerlendirilmiştir (Çizelge 3 ).

Karasu Çayı minimum ve maksimum sıcaklık değerleri sırasıyla $10.05^{\circ} \mathrm{C}$ (4. i̇st.) ve $27.17^{\circ} \mathrm{C}$ (1. ìst.)'da belirlenmiştir. Su kaynağının sıcaklıklığının iklime, yüksekliğe, suyun akış hızına ve su kaynağının yatak yapısına, atmosfer koşullarına bağlı olarak değiştiği bilinmektedir (Cirik ve Cirik, 2008) Su kalitesi çalışmalarında ana parametrelerden biri olan sıcaklık, tek başına anlamsız görünse de, çözünmüş oksijen, biyolojik oksijen ihtiyacı, pH gibi diğer parametrelerle anlamlı bir bütünlük yaratmaktadır (Gürel, 2011). Tepe ve Mutlu (2004) Hatay Harbiye kaynak suyunda ortalama su sıcaklığının $15.70^{\circ} \mathrm{C}$ olduğunu bildirmişlerdir. Bir başka çalışmada Bulut ve ark. (2012) Kestel Deresi istasyonlarında optimum sıcaklık değerlerinin 11.31$12.05^{\circ} \mathrm{C}$ arasında değiştiğini, Yıldız (2013) Giresun ilinin Gelevera deresinin sıcaklığının $13.19^{\circ} \mathrm{C}$ olduğunu belirtmişlerdir. Farklı bölgelerde farklı zamanlarda yapılan bu çalışmaların sonuçlarımızla paralel olduğu belirlenmiştir. 
Çizelge 1. Karasu Çayı fizikokimyasal parametrelerinin mevsimsel değişimi $(\mathrm{X} \pm \mathrm{SH})$, minimum-maksimum değerleri

Table 1. Seasonal variation of the Karasu Stream physicochemical parameters $(X \pm S D)$, minimum-maximum values

\begin{tabular}{|c|c|c|c|c|c|c|}
\hline & İst. & $\mathrm{n}$ & Yaz & Sonbahar & Kış & İlkbahar \\
\hline \multirow{8}{*}{ 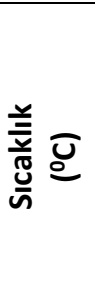 } & \multirow{2}{*}{1} & \multirow{2}{*}{12} & $25.47 \pm 0.57^{\mathrm{aA}}$ & $12.81 \pm 0.89^{a \mathrm{~B}}$ & $11.36 \pm 0.46^{\mathrm{aB}}$ & $16.55 \pm 0.40^{\mathrm{aC}}$ \\
\hline & & & $(23.15-27.17)$ & $(10.02-16.20)$ & $(10.14-13.24)$ & $(15.39-18.24)$ \\
\hline & \multirow{2}{*}{2} & \multirow[t]{2}{*}{12} & $25.23 \pm 0.55^{\mathrm{aA}}$ & $12.92 \pm 0.93^{\mathrm{aB}}$ & $11.70 \pm 0.35^{\mathrm{aB}}$ & $16.53 \pm 0.41^{\mathrm{aC}}$ \\
\hline & & & $(23.00-26.89)$ & (10.11-16.60) & (10.70-13.15) & $(15.23-18.10)$ \\
\hline & \multirow{2}{*}{3} & \multirow[t]{2}{*}{12} & $22.78 \pm 0.73^{\mathrm{aA}}$ & $12.99 \pm 0.86^{\mathrm{aB}}$ & $11.52 \pm 0.42^{\mathrm{aB}}$ & $16.70 \pm 0.28^{\mathrm{aC}}$ \\
\hline & & & $(20.88-25.80)$ & $(10.18-16.20)$ & (10.27-13.17) & $(15.56 \pm 17.47)$ \\
\hline & \multirow{2}{*}{4} & 12 & $22.83 \pm 0.86^{\mathrm{aA}}$ & $13.01 \pm 0.90^{\mathrm{aB}}$ & $11.49 \pm 0.46^{\mathrm{aB}}$ & $17.07 \pm 0.18^{\mathrm{ac}}$ \\
\hline & & & $(20.59-26.30)$ & $(10.15-16.45)$ & $(10.05-13.33)$ & $(16.30-17.60)$ \\
\hline \multirow{8}{*}{ O̊ } & \multirow{2}{*}{1} & 12 & $31.71 \pm 5.84^{\mathrm{aA}}$ & $2.83 \pm 0.62^{\mathrm{aB}}$ & $10.63 \pm 0.42^{\mathrm{aC}}$ & $36.03 \pm 0.55^{\mathrm{aD}}$ \\
\hline & & & (15.30-54.33) & $(1.60-5.30)$ & $4.30-20.30$ & $26.90-41.40$ \\
\hline & \multirow{2}{*}{2} & 12 & $27.75 \pm 5.70^{\mathrm{aA}}$ & $2.10 \pm 0.45^{\mathrm{aB}}$ & $10.53 \pm 0.39 \mathrm{ac}$ & $26.84 \pm 0.38^{\mathrm{aD}}$ \\
\hline & & & $(16.30-50.56)$ & $(1.10-3.90)$ & $4.50-19.90$ & $16.50-35.73$ \\
\hline & \multirow{2}{*}{3} & 12 & $30.99 \pm 5.22^{\mathrm{aA}}$ & $2.57 \pm 0.28^{\mathrm{aB}}$ & $13.62 \pm 0.30^{\mathrm{aC}}$ & $33.20 \pm 0.51^{\mathrm{aD}}$ \\
\hline & & & $(19.26-51.80)$ & $(1.90-3.70)$ & $6.30-25.66$ & $26.50-41.40$ \\
\hline & \multirow{2}{*}{4} & 12 & $13.14 \pm 1.97^{\mathrm{aA}}$ & $2.87 \pm 0.13^{\mathrm{aB}}$ & $14.73 \pm 0.40^{\mathrm{aC}}$ & $38.31 \pm 0.60^{\mathrm{aD}}$ \\
\hline & & & (7.10-20.53) & $(1.80-4.10)$ & $7.20-27.90$ & $27.30-55.73$ \\
\hline \multirow{8}{*}{ I } & \multirow{2}{*}{1} & 12 & $7.85 \pm 0.06^{\mathrm{aA}}$ & $7.46 \pm 0.05^{\mathrm{aB}}$ & $7.12 \pm 0.01^{\mathrm{aC}}$ & $7.30 \pm 0.14^{\mathrm{aC}}$ \\
\hline & & & $(7.65-8.14)$ & $(7.23-7.67)$ & $(7.08-7.20)$ & (6.75-7.74) \\
\hline & \multirow{2}{*}{2} & 12 & $7.70 \pm 0.03^{\mathrm{aA}}$ & $7.54 \pm 0.05^{\mathrm{aв}}$ & $7.14 \pm 0.01^{\mathrm{ac}}$ & $7.24 \pm 0.12^{\mathrm{ac}}$ \\
\hline & & & (7.57-7.85) & (7.11-7.63) & $(7.07-7.23)$ & $(6.75-7.65)$ \\
\hline & \multirow{2}{*}{3} & 12 & $7.65 \pm 0.08^{\mathrm{aA}}$ & $7.55 \pm 0.07^{\mathrm{aB}}$ & $7.13 \pm 0.03^{a c}$ & $7.23 \pm 0.14^{\mathrm{ac}}$ \\
\hline & & & (7.30-7.89) & (7.27-7.78) & (7.02-7.29) & (6.67-7.59) \\
\hline & 4 & 12 & $7.81 \pm 0.06^{\mathrm{aA}}$ & $7.41 \pm 0.07^{\mathrm{aB}}$ & $7.15 \pm 0.01^{\mathrm{ac}}$ & $7.37 \pm 0.10^{\mathrm{ac}}$ \\
\hline & 4 & & $(7.53-7.98)$ & $(7.19-7.71)$ & $(7.10-7.23)$ & $(6.96-7.71)$ \\
\hline & 1 & 12 & $521.55 \pm 12.06^{\mathrm{aA}}$ & $17.27 \pm 1.30^{\mathrm{aB}}$ & $63.44 \pm 12.89^{a C}$ & $241.95 \pm 9.45^{\mathrm{aD}}$ \\
\hline & 1 & & $484.53-566.86$ & $12.16-20.74$ & $37.40-115.00$ & $204.96-267.13$ \\
\hline & $?$ & 12 & $523.61 \pm 17.18^{\mathrm{Aa}}$ & $11.34 \pm 1.31^{\mathrm{aB}}$ & $57.75 \pm 18.14^{\mathrm{aC}}$ & $240.49 \pm 10.78^{\mathrm{aD}}$ \\
\hline 呈 & 2 & & $483.66-592.00$ & $6.16-14.64$ & $11.59-129.32$ & $199.47-272.50$ \\
\hline$\overline{\underline{T}}$ है & & 12 & $554.25 \pm 24.78^{\mathrm{aA}}$ & $24.99 \pm 0.54^{\mathrm{aB}}$ & $70.35 \pm 8.86^{\mathrm{ac}}$ & $258.30 \pm 12.19 \mathrm{aD}$ \\
\hline & 3 & & $466.33-633.13$ & $23.13-26.84$ & $43.79-103.96$ & $214.11-298.26$ \\
\hline & 4 & 12 & $542.54 \pm 10.71^{\mathrm{aA}}$ & $43.18 \pm 2.54^{\mathrm{aB}}$ & $81.54 \pm 16.77^{\mathrm{ac}}$ & $254.16 \pm 7.82^{\mathrm{aD}}$ \\
\hline & 4 & & $519.30-585.33$ & $37.21-53.30$ & 40.99-148.11 & $223.26-265.33$ \\
\hline & & 12 & $2.73 \pm 0.11^{\mathrm{aA}}$ & $5.54 \pm 0.21^{\mathrm{aB}}$ & $6.61 \pm 0.09^{a c}$ & $5.83 \pm 0.14^{\mathrm{aC}}$ \\
\hline & 1 & & $(2.20-3.40)$ & $(4.60-6.50)$ & $(6.20-7.10)$ & $(5.20-6.60)$ \\
\hline & $?$ & 12 & $3.46 \pm 0.48^{\mathrm{aA}}$ & $5.78 \pm 0.11^{\mathrm{aB}}$ & $6.47 \pm 0.08^{a c}$ & $5.57 \pm 0.17^{\mathrm{ac}}$ \\
\hline 0 ت & 2 & & $(2.20-5.60)$ & $(5.40-6.40)$ & $(6.10-6.90)$ & $(4.80-6.30)$ \\
\hline Ч & & 12 & $3.83 \pm 0.21^{\mathrm{aA}}$ & $5.74 \pm 0.24^{\mathrm{aB}}$ & $6.84 \pm 0.07^{a c}$ & $5.82 \pm 0.17^{a c}$ \\
\hline & 3 & & $(3.10-4.60)$ & $(4.60-6.60)$ & $(6.50-7.20)$ & $(5.20-6.60)$ \\
\hline & 4 & 12 & $4.64 \pm 0.25^{\mathrm{aA}}$ & $5.87 \pm 0.12^{\mathrm{aB}}$ & $6.77 \pm 0.07^{\mathrm{ac}}$ & $5.95 \pm 0.15^{\mathrm{ac}}$ \\
\hline & 4 & & $(3.40-5.60)$ & $(5.40-6.40)$ & $(6.50-7.10)$ & $(5.20-6.60)$ \\
\hline & & 12 & $13.15 \pm 3.97^{\mathrm{aA}}$ & $17.20 \pm 2.22^{\mathrm{aA}}$ & $19.79 \pm 0.21^{\mathrm{aA}}$ & $16.34 \pm 3.66^{\mathrm{aA}}$ \\
\hline & 1 & & (3.04-28.88) & $(8.25-22.12)$ & $(19.01-20.60)$ & $(1.70-24.59)$ \\
\hline & $?$ & 12 & $11.81 \pm 2.53^{\mathrm{aA}}$ & $10.49 \pm 0.63^{\mathrm{aA}}$ & $9.09 \pm 0.22^{\mathrm{aA}}$ & $15.41 \pm 3.59^{a A}$ \\
\hline ह & 2 & & $(2.85-20.52)$ & $(8.30-12.92)$ & $(8.30-9.88)$ & $(1.19-24.59)$ \\
\hline 竎 & 3 & 12 & $2.99 \pm 0.19^{\mathrm{aA}}$ & $19.94 \pm 6.06^{\mathrm{aA}}$ & $5.45 \pm 0.23^{\mathrm{aA}}$ & $10.88 \pm 2.60^{\mathrm{aA}}$ \\
\hline & 3 & & $(2.1-3.49)$ & $(6.80-44.30)$ & $(4.50-6.15)$ & $(0.79-18.24)$ \\
\hline & & 12 & $2.45 \pm 0.21^{\mathrm{aA}}$ & $18.57 \pm 6.45^{\mathrm{aA}}$ & $6.14 \pm 0.26^{\mathrm{aA}}$ & $16.96 \pm 5.07^{\mathrm{aA}}$ \\
\hline & 4 & & $(1.62-3.13)$ & (3.75-44.35) & $(5.22-7.10)$ & $(0.80-35.72)$ \\
\hline & & 12 & $254.50 \pm 2.50^{\mathrm{abA}}$ & $282.02 \pm 2.18^{\mathrm{abB}}$ & $289.51 \pm 0.68^{\mathrm{abB}}$ & $284.80 \pm 0.69^{a b B}$ \\
\hline & 1 & & $(248.50-264.50)$ & $(273.20-287.70)$ & $(287.60-292.30)$ & $(282.30-287.40)$ \\
\hline & & 12 & $260.57 \pm 5.53^{\mathrm{abA}}$ & $283.35 \pm 0.82^{\mathrm{abB}}$ & $286.13 \pm 0.46^{\mathrm{abB}}$ & $279.93 \pm 2.05^{\mathrm{abB}}$ \\
\hline$\hat{\alpha} \geq$ & 2 & & $(248.50-282.90)$ & $(280.00-285.60)$ & $(284.20-287.40)$ & $(272.30-286.90)$ \\
\hline & & 12 & $286.13 \pm 0.46^{\mathrm{abB}}$ & $279.93 \pm 2.05^{\mathrm{abB}}$ & $286.13 \pm 0.46^{a b B}$ & $279.93 \pm 2.05^{\mathrm{abB}}$ \\
\hline & 3 & & $(261.00-268.40)$ & $(273.50-287.60)$ & $(288.20-292.70)$ & $(280.20-287.90)$ \\
\hline & 4 & 12 & $269.54 \pm 1.31^{\mathrm{aA}}$ & $287.52 \pm 1.17^{\mathrm{aB}}$ & $289.08 \pm 0.84^{\mathrm{aB}}$ & $284.93 \pm 0.69^{a \mathrm{~B}}$ \\
\hline & 4 & & $(264.10-272.70)$ & $(283.20-291.90)$ & $(287.20-292.80)$ & $(282.50-287.70)$ \\
\hline
\end{tabular}

$\mathrm{A}, \mathrm{B}, \mathrm{C}$ harfleri mevsimler arası farklılıkları $(P<0.05), \mathrm{a}, \mathrm{b}, \mathrm{c}$ harfleri istasyonlar arası farklılıkları $(P<0.05)$, Standart hata $( \pm \mathrm{SH}), \mathrm{n}=$ Toplam örnekleme sayısı. 
Çizelge 1'in devamı. Karasu Çayı fizikokimyasal parametrelerinin mevsimsel değişimi ( $\mathrm{X} \pm \mathrm{SH})$, minimum-maksimum değerleri ve Sinop ili İklim verileri (Sıcaklık-Yağış)

Continuation of Table 1. Seasonal variation of the physicochemical parameters of Karasu Stream (XISD), minimummaximum values and Sinop province Climate data (Temperature-Precipitation)

\begin{tabular}{|c|c|c|c|c|c|c|}
\hline & İst. & $\mathbf{n}$ & Yaz & Sonbahar & Kış & ilkbahar \\
\hline \multirow{8}{*}{ 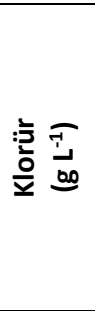 } & \multirow{2}{*}{1} & \multirow[t]{2}{*}{12} & $0.28 \pm 0.08^{\mathrm{aA}}$ & $0.46 \pm 0.16^{\mathrm{aA}}$ & $0.15 \pm 0.01^{\mathrm{aA}}$ & $0.13 \pm 0.02^{\mathrm{aA}}$ \\
\hline & & & $(0.02-0.63)$ & $(0.14-1.42)$ & $(0.14-0.17)$ & $(0.01 .-0.19)$ \\
\hline & \multirow{2}{*}{2} & \multirow[t]{2}{*}{12} & $0.37 \pm 0.14^{\mathrm{aA}}$ & $0.25 \pm 0.09^{\mathrm{aA}}$ & $0.07 \pm 0.00^{\mathrm{aA}}$ & $0.12 \pm 0.02^{\mathrm{aA}}$ \\
\hline & & & $(0.01-0.99)$ & $(0.03-0.71)$ & $(0.04-0.09)$ & (0.01-0.19 \\
\hline & \multirow{2}{*}{3} & \multirow[t]{2}{*}{12} & $0.13 \pm 0.05^{\mathrm{aA}}$ & $0.15 \pm 0.04^{\mathrm{aA}}$ & $0.04 \pm 0.01^{\mathrm{aA}}$ & $0.08 \pm 0.02^{\mathrm{aA}}$ \\
\hline & & & $(0.01-0.42)$ & $(0.03-0.35)$ & $(0.03-0.06)$ & $(0.00-0.14)$ \\
\hline & \multirow{2}{*}{4} & \multirow[t]{2}{*}{12} & $0.13 \pm 0.04^{\mathrm{aA}}$ & $0.15 \pm 0.05^{\mathrm{aA}}$ & $0.04 \pm 0.01^{\mathrm{aA}}$ & $0.13 \pm 0.04^{\mathrm{aA}}$ \\
\hline & & & $(0.01-0.35)$ & $(0.03-0.35)$ & $(0.03-0.05)$ & $(0.00-0.29)$ \\
\hline \multirow{8}{*}{ 员 } & \multirow{2}{*}{1} & \multirow[t]{2}{*}{12} & $0.85 \pm 0.08^{\mathrm{aA}}$ & $2.03 \pm 0.69^{\mathrm{aB}}$ & $0.33 \pm 0.04^{\mathrm{aA}}$ & $0.53 \pm 0.08^{\mathrm{aA}}$ \\
\hline & & & $(0.40-1.20)$ & $(0.52-4.80)$ & $(0.10-0.50)$ & $(0.20-0.90)$ \\
\hline & \multirow{2}{*}{2} & \multirow[t]{2}{*}{12} & $1.20 \pm 0.19^{a b A}$ & $2.96 \pm 0.70^{\mathrm{abB}}$ & $0.88 \pm 0.03^{\mathrm{abA}}$ & $1.79 \pm 0.29 \mathrm{abA}$ \\
\hline & & & $(0.60-2.20)$ & $(1.00-5.80)$ & $(0.70-1.10)$ & $(1.00-3.00)$ \\
\hline & \multirow{2}{*}{3} & \multirow[t]{2}{*}{12} & $1.46 \pm 0.21^{\mathrm{abA}}$ & $2.44 \pm 0.60^{\mathrm{abB}}$ & $0.93 \pm 0.04^{\mathrm{abA}}$ & $0.94 \pm 0.18^{\mathrm{abA}}$ \\
\hline & & & $(0.60-2.40)$ & $(1.00-5.00)$ & $(0.70 \pm 1.10)$ & $(0.20-1.50)$ \\
\hline & \multirow{2}{*}{4} & \multirow[t]{2}{*}{12} & $1.75 \pm 0.27^{\mathrm{bA}}$ & $3.61 \pm 0.49^{\mathrm{bB}}$ & $2.32 \pm 0.04^{\mathrm{bA}}$ & $2.24 \pm 0.22^{\mathrm{bA}}$ \\
\hline & & & $(0.60-2.80)$ & $(2.40-5.80)$ & $(2.10-2.50)$ & $(1.20-2.90)$ \\
\hline \multirow{8}{*}{ 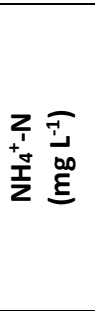 } & & 12 & $0.24 \pm 0.03^{\mathrm{bA}}$ & $0.12 \pm 0.01^{\mathrm{bB}}$ & $0.12 \pm 0.01^{\mathrm{bB}}$ & $0.32 \pm 0.01^{\mathrm{bA}}$ \\
\hline & 1 & & $(0.09-0.32)$ & $(0.09-0.16)$ & $(0.08-0.19)$ & $(0.26-0.35)$ \\
\hline & & 12 & $0.25 \pm 0.03^{\mathrm{abA}}$ & $0.10 \pm 0.01^{\mathrm{abB}}$ & $0.09 \pm 0.01^{\mathrm{abB}}$ & $0.28 \pm 0.01^{\mathrm{abA}}$ \\
\hline & 2 & & $(0.10-0.36)$ & $(0.07-0.15)$ & $(0.06-0.138)$ & $(0.23-0.30)$ \\
\hline & & 12 & $0.15 \pm 0.07^{\mathrm{abA}}$ & $0.00 \pm 0.00^{\mathrm{abB}}$ & $0.01 \pm 0.00^{\mathrm{abB}}$ & $0.16 \pm 0.03^{\mathrm{abA}}$ \\
\hline & 3 & & $(0.00-0.46)$ & $(0.00-0.01)$ & $(0.00-0.05)$ & $(0.03-0.27)$ \\
\hline & & 12 & $0.09 \pm 0.04^{\mathrm{abA}}$ & $0.01 \pm 0.00^{\mathrm{abB}}$ & $0.02 \pm 0.01^{\mathrm{abB}}$ & $0.15 \pm 0.03^{\mathrm{abA}}$ \\
\hline & 4 & & $(0.00-0.26)$ & $(0.00-0.02)$ & $(0.00-0.06)$ & $(0.02-0.25)$ \\
\hline & & 12 & $65.27 \pm 3.51^{\mathrm{aA}}$ & $0.81 \pm 0.16^{\mathrm{aB}}$ & $0.31 \pm 0.03^{\mathrm{aB}}$ & $3.33 \pm 0.31^{\mathrm{aB}}$ \\
\hline & 1 & & $(1.70-188.29)$ & $(0.42-1.70)$ & $(0.12-0.42)$ & $(2.13-4.86)$ \\
\hline & & 12 & $68.44 \pm 3.14^{\mathrm{aA}}$ & $2.21 \pm 0.48^{\mathrm{aB}}$ & $0.63 \pm 0.11^{\mathrm{aB}}$ & $2.69 \pm 0.17^{\mathrm{aB}}$ \\
\hline$\approx \widetilde{I}$ & 2 & 12 & $(1.27-198.51)$ & $(1.11-4.26)$ & $(0.29-1.27)$ & $(2.13-3.83)$ \\
\hline & & 12 & $65.93 \pm 3.34^{\mathrm{aA}}$ & $3.33 \pm 0.48^{\mathrm{aB}}$ & $1.28 \pm 0.17^{\mathrm{aB}}$ & $1.27 \pm 0.12^{\mathrm{aB}}$ \\
\hline & 3 & & $(0.85-192.12)$ & $(2.03-5.53)$ & $(0.42-1.70)$ & $(0.79-1.70)$ \\
\hline & & 12 & $76.77 \pm 3.47^{\mathrm{aA}}$ & $1.87 \pm 0.40^{\mathrm{aB}}$ & $0.34 \pm 0.08^{a B}$ & $1.52 \pm 0.06^{\mathrm{aB}}$ \\
\hline & 4 & & $(2.13-224.50)$ & $(0.42-3.83)$ & $(0.04-0.85)$ & $(1.27-1.70)$ \\
\hline & & 12 & $147.39 \pm 0.89^{a A}$ & $20.11 \pm 3.09^{\mathrm{aB}}$ & $36.05 \pm 6.70^{\mathrm{aB}}$ & $77.13 \pm 7.07 \mathrm{aB}$ \\
\hline & 1 & & $115.7-202.98$ & $13.63-32.46$ & $26.49-45.27$ & $59.23-88.66$ \\
\hline & & 12 & $165.15 \pm 1.63^{\mathrm{abA}}$ & $45.29 \pm 0.55^{\mathrm{abB}}$ & $32.8 \pm 4.78^{\mathrm{abB}}$ & $55.8 \pm 5.86^{\mathrm{abB}}$ \\
\hline$\Sigma \bar{I}$ & 2 & & $147.60-189.56$ & $43.13-46.69$ & $28.01-36.56$ & $32.38-68.01$ \\
\hline రิ & & 12 & $105.95 \pm 4.93^{\mathrm{bcA}}$ & $15.79 \pm 0.87 \mathrm{bcB}$ & $23.55 \pm 3.63^{\mathrm{bcB}}$ & $38.27 \pm 4.99 \mathrm{bcB}$ \\
\hline & 3 & & $79.90-157.00$ & $12.71-18.73$ & $10.46-41.93$ & $23.05-57.06$ \\
\hline & & 12 & $95.79 \pm 1.41^{\mathrm{cA}}$ & $66.19 \pm 0.97^{\text {св }}$ & $28.69 \pm 5.65^{\mathrm{cB}}$ & $41.00 \pm 6.19^{\mathrm{B}}$ \\
\hline & 4 & & 78.33-110.49 & $62.36-68.66$ & $26,20-30,73$ & $25.31-65.43$ \\
\hline & & 12 & $0.264 \pm 0.124^{\mathrm{aA}}$ & $0.036 \pm 0.009^{\mathrm{aA}}$ & $0.065 \pm 0.015^{\mathrm{aA}}$ & $0.130 \pm 0.015^{\mathrm{aA}}$ \\
\hline & 1 & & $(0.004-0.770)$ & $(0.001-0.100)$ & $(0.030-0.140)$ & $(0.010-0.300)$ \\
\hline & & 12 & $0.298 \pm 0.143^{\mathrm{aA}}$ & $0.077 \pm 0.033^{\mathrm{aA}}$ & $0.237 \pm 0.135^{\mathrm{aA}}$ & $0.371 \pm 0.186^{\mathrm{aA}}$ \\
\hline$\sum_{\underline{I}} \bar{I}$ & 2 & & $(0.010-0.880)$ & $(0.010-0.300)$ & $(0.020-1.200)$ & $(0.010-1.400)$ \\
\hline$\stackrel{0}{E}$ & & 12 & $0.190 \pm 0.081^{\mathrm{aA}}$ & $0.027 \pm 0.009^{a A}$ & $0.041 \pm 0.017^{\mathrm{aA}}$ & $0.069 \pm 0.024^{\mathrm{aA}}$ \\
\hline & 3 & & $(0.006-0.540)$ & $(0.005-0.070)$ & $(0.010-0.14)$ & $(0.002-0.164)$ \\
\hline & & 12 & $0.174 \pm 0.079 \mathrm{aA}$ & $0.051 \pm 0.009^{a A}$ & $0.062 \pm 0.012^{\mathrm{aA}}$ & $0.094 \pm 0.035^{a A}$ \\
\hline & 4 & & $(0.001-0.500)$ & $(0.023-0.095)$ & $(0.012-0.137)$ & $(0.009-0.150)$ \\
\hline Sıcaklı & & 1936 - & 21.83 & 16.20 & 7.60 & 10.90 \\
\hline Yağış & & 2016 & 36.13 & 79.20 & 71.60 & 41.83 \\
\hline Sıcakl & & & & 15.7 & & 15.1 \\
\hline Yağış & & & 2014 yılı ortalaması & 703.6 & 2015 yılı ortalaması & 691.5 \\
\hline
\end{tabular}

A, B, C harfleri mevsimler arası farklııkları $(P<0.05), a, b, c$ harfleri istasyonlar arası farklılıkları $(P<0.05)$, Standart hata $( \pm S H), n=$ Toplam örnekleme sayısı. Sıcaklık ve Yağış (Anonim, 2015b -2016a). 
Çalışmamızda serbest $\mathrm{CO}_{2}$ değerleri çözünmüş oksijen değerleri ile ters orantılı olduğu saptanmıştır. Karasu Çayı serbest $\mathrm{CO}_{2}$ değerlerinin 1.10-55.73 $\mathrm{mg} \mathrm{L}^{-1}$ aralığında olduğu tespit edilmiştir (Çizelge 1 ). Karbondioksit suda çok kolay çözünür. Su kaynaklarına havadan geçebildiği gibi organik moleküllerin ayrışması ya da organizma faaliyetlerinin artmasıyla solunum olaylarının daha fazla olması $\mathrm{CO}_{2}$ oranının artış nedeni olmaktadır. Gedik ve ark. (2010), Rize Fırtına Deresi'nde yapmış oldukları çalışma sonucu $0.88-4.10 \mathrm{mg} / \mathrm{L}$ aralığında saptamıştır. Çalışmamız değerlerinin bu çalışma ile farklılık göstermesi su kaynaklarının farklı olmasındandır. $\mathrm{CO}_{2}$ korelasyon değerlerinin alkalinite, $\mathrm{NH}_{4}, \mathrm{OM}, \mathrm{TAKM}$ ile doğru orantılı olduğu (sırasıyla $r=0.663, r=0.733, r=0.476, r=0.464), B^{\circ O I_{5}}$ ters orantılı ( $r=$ -0.485 ) olduğu saptanmıştır ( $P \leq 0.001$; Çizelge 3$)$.

Karasu Çayı pH değerlerinin mevsimsel değişimleri incelendiğinde; minimum değer ilkbahar mevsiminde
6.67 ile 3.ist.'da ve maksimum değer yaz mevsiminde 8.14 ile 1.ist.' da olduğu saptanmıştır. pH değerleri sudaki karbonat $\left(\mathrm{CO}_{3}{ }^{-2}\right)$, bikarbonat $\left(\mathrm{HCO}_{3}{ }^{-}\right)$ve serbest karbondioksit $\left(\mathrm{CO}_{2}\right)$ miktarına bağlı olarak değişebilir, ancak bu değişiklikler birçok faktörden kaynaklanabilmektedir. Öner ve Çelik (2001), Şengün (2013) ve Dinçer (2014) pH değerlerini sırasıyla 7.60 (Gediz Nehri'nde), 7.42 (Giresun Aksu Deresi'nde) ve 7.92 (Giresun İli Çanakçı Deresi'nde) olduğunu bildirmişlerdir. $\mathrm{pH}$ korelasyon değerlerinin alkalinite, $\mathrm{H}_{2} \mathrm{~S}$, OM ile doğru orantılı olduğu (sırasıyla $r=0.674$, $r=0.825, r=0.719$ ), ÇO, ORP ile ters orantılı (sırasıyla $r=-$ $0.877, r=-0.853)$ olduğu saptanmıştır $(P \leq 0.001$; Çizelge 3). Karasu Çayı pH değeri Yerüstü Su Kalitesi Yönetmeliği ile karşılaştırıldığında I.-II. Sınıf Kalitededir (Çizelge 4).

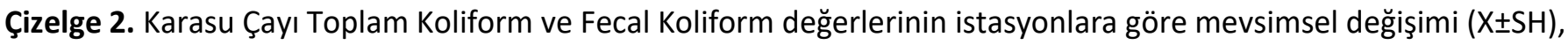
minimum-maksimum değerleri

Table 2. Seasonal change of Karasu Stream Total Coliform and Fecal Coliform values (X士SD), minimum-maximum values

\begin{tabular}{|c|c|c|c|c|c|c|}
\hline & İst. & $\mathrm{n}$ & Yaz & Sonbahar & Kış & İkbahar \\
\hline \multirow{8}{*}{ 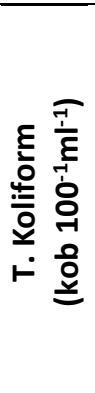 } & \multirow{2}{*}{1} & 12 & $721.22 \pm 32.19^{\mathrm{bA}}$ & $360.44 \pm 16.12^{\mathrm{bB}}$ & $73.00 \pm 3.68^{\mathrm{bc}}$ & $328.66 \pm 14.55^{\mathrm{bB}}$ \\
\hline & & & $(525-882)$ & $(262-441)$ & $(52-89)$ & $(238-400)$ \\
\hline & \multirow{2}{*}{2} & 12 & $676.33 \pm 26.11^{\mathrm{bA}}$ & $337.88 \pm 13.07^{\mathrm{bB}}$ & $47.16 \pm 1.88^{\mathrm{bc}}$ & $268.77 \pm 10.49^{\mathrm{bB}}$ \\
\hline & & & (525-799) & (262-399) & $(37-57)$ & $(210-315)$ \\
\hline & \multirow{2}{*}{3} & 12 & $542.88 \pm 36.87^{\mathrm{bA}}$ & $271.22 \pm 18.46^{\mathrm{bB}}$ & $67.55 \pm 4.64^{\mathrm{bc}}$ & $285.22 \pm 19.35^{\mathrm{bB}}$ \\
\hline & & & (405-689) & $(202-344)$ & $(50-85)$ & $(213-362)$ \\
\hline & \multirow{2}{*}{4} & 12 & $257.88 \pm 14.26^{\mathrm{aA}}$ & $165.66 \pm 6.64^{\mathrm{aB}}$ & $32.88 \pm 1.33^{\mathrm{aC}}$ & $131.88 \pm 7.12^{\mathrm{aB}}$ \\
\hline & & & $(201-305)$ & $(135-190)$ & $(27-38)$ & $(105-163)$ \\
\hline \multirow{8}{*}{ 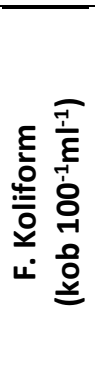 } & \multirow{2}{*}{1} & 12 & $627.33 \pm 4.11^{\mathrm{cA}}$ & $317.55 \pm 2.16^{\mathrm{CB}}$ & $48.88 \pm 0.97^{\mathrm{CC}}$ & $270.22 \pm 2.83^{\mathrm{CB}}$ \\
\hline & & & $(612-644)$ & $(305-327)$ & $(47-53)$ & $(253-282)$ \\
\hline & \multirow{2}{*}{2} & 12 & $539.11 \pm 5.78^{\mathrm{cA}}$ & $306.00 \pm 9.09^{\mathrm{CB}}$ & $36.88 \pm 2.42^{\mathrm{cC}}$ & $218.66 \pm 7.17^{\mathrm{CB}}$ \\
\hline & & & $(520-568)$ & $(258-337)$ & $(24-47)$ & $(187-248)$ \\
\hline & \multirow{2}{*}{3} & 12 & $519.66 \pm 34.43^{\mathrm{bcA}}$ & $229.11 \pm 7.48^{\mathrm{bcB}}$ & $32.55 \pm 2.17^{\mathrm{bcc}}$ & $235.66 \pm 11.92^{b c B}$ \\
\hline & & & $(405-649)$ & $(202-267)$ & $(21-41)$ & $(205-305)$ \\
\hline & \multirow{2}{*}{4} & 12 & $197.88 \pm 2.77^{\mathrm{abA}}$ & $128.44 \pm 5.12^{\mathrm{abB}}$ & $24.88 \pm 0.99^{\mathrm{abc}}$ & $111.33 \pm 5.60^{\mathrm{abB}}$ \\
\hline & & & $(185-213)$ & $(105-148)$ & $(19-29)$ & $(87-143)$ \\
\hline
\end{tabular}

A, B, C harfleri mevsimler arası farklılıkları ( $\mathrm{P}<0.05)$, a, b, c harfleri istasyonlar arası farklılıkları $(\mathrm{P}<0.05)$, Standart hata $( \pm \mathrm{SH})$, $\mathrm{n}=$ Toplam örnekleme sayısı.

Akarsularda alkalinite; jeolojik yapı, kaya, toprak, tuz, bitki aktivitesi ve endüstriyel atık salınımından etkilenmektedir (Anonymous, 1997b). Toplam alkalinite genel olarak $\mathrm{mg} \mathrm{CaCO}_{3} \mathrm{~L}^{-1}$ şeklinde ifade edilir ve bikarbonat, karbonat ve hidroksit bileşenlerinden meydana gelmektedir. Alkalinite suyun asitleri nötralize edebilme kabiliyeti veya tamponlama miktarının bir ölçüsüdür. Doğal sularda alkalilik, 20-300 $\mathrm{mg} \mathrm{CaCO}_{3} \mathrm{~L}^{-1}$ arasında olmaktadır. Alkalinitesi $<20 \mathrm{mg} / \mathrm{L}$ olanlar düşük alkali sular, $>300 \mathrm{mg} \mathrm{L}^{-1}$ olanlar ise yüksek alkali sular şeklinde kabul edilmektedir. Sucul organizmalar için alkalinite değeri 75-150 $\mathrm{mg} \mathrm{L}^{-1}$ arasında değişmektedir (Boyd, 1995). Çalışmada, Karasu Çayı'nın alkalinite değerleri 11.34-554 mg $\mathrm{L}^{-1}$ aralığında olduğu belirlenmiştir (Çizelge 1). Yapılan diğer çalışmalarda ise; Küçük (2007) Büyük Menderes Nehri'ndeki çalışmasında 
alkaliniteyi 200-500 mg/L değer aralığında, Dinçer (2014) Çanakçı Deresi'nde ortalama olarak alkaliniteyi 39-45 mg $\mathrm{L}^{-1}$ değer aralığında, Tepe ve arkadaşları (2006) Hatay Erzin Hasan Çayı'nda yapmış oldukları çalışmada ortalama alkaliniteyi $141,42 \mathrm{mg} \mathrm{L}^{-1}$, Giresun ili Aksu Deresi'nde Şengün (2013) $115,47 \mathrm{mg} \mathrm{L}^{-1}$ ve Gelevera Deresi'nde Yıldız (2013) $33 \mathrm{mg} \mathrm{L} \mathrm{L}^{-1}$ olarak tespit etmişlerdir. Alkalinite korelasyon değerlerinin $\mathrm{NH}_{4}, \mathrm{OM}$, TAKM ile doğru orantılı olduğu (sırasıyla $r=0.543$, $\mathrm{r}=0.908, \mathrm{r}=0.857, \mathrm{r}=0.621 ; P \leq 0.001)$, ÇO, iletkenlik, ORP ile ters orantılı (sırasıyla $\mathrm{r}=-0.839, \mathrm{r}=0.435, \mathrm{r}=-0.868 ; P$ $\leq 0.001$ ) olduğu saptanmıştır (Çizelge 3 ).

Karasu Çayı ÇO değerlerinin mevsimsel değişimleri incelendiğinde, minimum değer yaz mevsiminde $2.20 \mathrm{mg}$ $\mathrm{L}^{-1}$ ile 1 . ve 2 . istasyonlarda ve maksimum değer kış mevsiminde $7.10 \mathrm{mg} \mathrm{L}^{-1}$ ile 4 . istasyonda ölçülmüştür. çO değerlerinin, mevsimsel hava ve su sıcaklıklarının değişimden etkilendiği belirlenmiş̧ir. Bu durum, gazların çözünürlüğünün sıcaklık ile ters orantılı olduğunu göstermektedir. Oksijen gazı suda çözünen en önemli gazlardan biridir. Oksijenin sudaki çözünürlüğü sıcaklı̆̆a, tuzluluğa, fotosentetik aktivitelere ve atmosfer basıncına bağlı olarak değişmektedir (Gündoğdu, 1995; Tayhan, 2012). Karasu Çayı ÇO değerlerinin mevsimsel değişimleri Kıtaiçi Yerüstü Su Kaynaklarının Genel Kimyasal ve Fizikokimyasal Parametreler Açısından Sınıflarına Göre Kalite Kriterleri'ne göre incelendiğinde (Anonim, 2016), su kalitesi II. ve IV. Sınıftır (Çizelge 4). Dünya Sağlık Örgütü'nün (WHO) verilerine göre, nehir sularının ÇO değeri $\geq 5 \mathrm{mg} \mathrm{L}^{-1}$ olmalıdır. Elde edilen ÇO konsantrasyonlarının yaz mevsiminde WHO standartlarının altında, diğer mevsimlerde ise üstünde bulunmuştur (Anonim, 2018). Avrupa Birliği'nin Su Çerçeve Direktifi'ne göre, 2-6 $\mathrm{mg} \mathrm{L}^{-1}$ aralığında ÇO değeri yetersiz olarak belirtilmektedir (Anonymous, 2000). Çalışmamız sonucunda elde edilen çO değerleri 2.20 $7.20 \mathrm{mg} \mathrm{L}^{-1}$ aralığında olduğu saptanmıştır. Bu durum, su kaynağının ÇO değerlerinin zaman zaman düşük olduğu ve su ekosistemini olumsuz etkileyebileceği fikrini oluşturmaktadır. ÇO konsantrasyonu suyun kirlilik potansiyeli, içerisindeki OM miktarı ve suyun kendi kendini temizleme derecesi hakkında fikir sahibi olmamıza yardımcı olmaktadır (Kara ve Çömlekcioğlu, 2004). Asi Nehri'nde Taşdemir ve Göksu tarafından yapılan çalışmada (Taşdemir ve Göksu, 2001), çO miktarı 2.6 ile $9.9 \mathrm{mg} \mathrm{L}^{-1}$ arasında belirlenmiştir. Hatay Karamanlı Göleti (Tepe ve ark., 2004) ve Trabzon İyidere Nehri'nde (Verep ve ark., 2005) yapılmış çalışmalarda, ortalama ÇO konsantrasyonu sırasıyla $9.31 \mathrm{mg} \mathrm{L}^{-1}$ ve $11.10 \mathrm{mg} \mathrm{L}^{-1}$ bulunmuştur. Çalışmamızdan elde edilen çO değerleri önceki araştırmalardan farklıdır ve bölgesel farklılıkların etkili olduğu düşünülmüştür. Ayrıca sonuçlarımız Karasu Çayı'nda çevresel etkilerin yüksek olduğu ve kirlilik sorunu ile karşı karşıya olduğunu göstermektedir.
Minimum iletkenlik $1.62 \mu \mathrm{s} \mathrm{cm}^{-1}$ olmasına rağmen, maksimum iletkenlik değeri $44.35 \mu \mathrm{s} \mathrm{cm}^{-1}$ bulunmuş olup, her iki değerin de 4.ist.'da olduğu saptanmıştır. iletkenlik değerleri genellikle $1000 \mu \mathrm{cm}^{-1}$ 'nin altında değişim göstermiştir (Çizelge 1). WHO standartlarına göre nehir sularında iletkenliğin maksimum $1000 \mu \mathrm{s} \mathrm{cm}$ ${ }^{1}$ olduğu bildirilmiştir (Leong ve ark., 2018). Illetkenliğin $1000 \mu \mathrm{sm}^{-1}$ yi aşan su kaynaklarında kirliliğin olduğu kabul edilmektedir (Kara ve Çömlekcioğlu, 2004). Elektrik iletkenliğinin suda çözünen tuzlara, yoğunluklarına ve su sıcaklığına bağlı olarak değiştiği bilinmektedir (Er, 2014). Karasu Çayı'nın mevsimsel iletkenlik değerleri incelendiğinde, İstatistik olarak farklılık önemli bulunmamakla birlikte istasyonların homojen bir dağılım göstermediği belirlenmiştir. Bunun nedeni; öncelikle iklim koşullarındaki fark, su kaynağının deniz suyuyla zaman zaman birleşmesi, mevsimsel sıcaklık farklılıkları, yağış değişkenliğinin olması ve su kaynağının diğer kollarının varlıkları gösterilebilir. Çalışmalarda, iletkenlik değerleri Emiralem Deresi'nde (Sukatar ve ark., 2006), $239-322 \mu \mathrm{sm}^{-1}$ ve Trabzon ili nehirlerinde (Gültekin ve ark., 2012), $28-450 \mu \mathrm{cm}^{-1}$ arasında belirlenmiştir. Bir başka çalışmada ise Ordu Ulugöl'ün iletkenlik değeri $187.46 \mu \mathrm{s} \mathrm{cm}^{-1}$ olduğu gösterilmiştir (Taş ve ark., 2010).

ORP, redoks potansiyelidir ve suyun kalitesini belirleyen parametrelerden birisidir. ORP (milivolt:mV)'nin pozitif değer alması suyun oksidasyon özelliğini, bozucu, paslandırıcı etkisini, negatif değer alması ise bozulmayı paslanmayı engelleyici özellik taşıdığını ifade etmektedir (Yıldız, 2013; Dinçer, 2014). Karasu Çayı'nın ortalama ORP değerleri $254.50 \pm 2.50 \mathrm{mV}$ (1.ist., Yaz) ve $289.80 \pm 0.84 \mathrm{mV}$ (4.ist., Kış) arasında olduğu bulunmuştur (Çizelge 1). Farklı bölgelerde yapılmış çalışmalarda ORP değerleri Giresun ili Çanakçı Deresinde -94.18 mV (Dinçer, 2014), Aksu Deresinde -93.1 mV (Şengün 2013) olduğu tespit edilmiştir. ORP bir çözeltinin veya su ortamının oksitleme ve indirgeme gücünü milivolt (mV) olarak belirleyen bir ölçümdür (Sigg, 2000; James ve ark., 2004). ORP değeri positif ise suyun okside olabileceğini ve çürütücü (bozucu) etkilerinin olduğunu, negatif ise suyun engelleyici özellikte ve antioksidan güce sahip olduğunu gösterir. Doğal sular pozitif ORP değerine sahiptir. Sedimanlarda anaerobik koşullar oluştukça, mikroorganizmaların farklı grupları sırasıyla elektron alıcılarını $\left(\mathrm{O}_{2}, \mathrm{NO}_{3}^{-}, \mathrm{Mn}^{+4}, \mathrm{Fe}^{+3}, \mathrm{SO}_{4}^{-2}\right.$ ve $\left.\mathrm{CO}_{2}\right)$ kullanırlar. $\mathrm{Bu}$ elektron alıcılarını kullanan mikroorganizmalar yumuşak zeminlerdedir ve ard arda meydana gelen bir dizi reaksiyonlar sediman yataklarının derinliklerinde sıklıkla tekrarlanır (Guo ve ark., 1997). Karasu Çayı ORP (248.50 - 292.80 aralığında) değerinin mevsimsel değişimlerinde çok büyük değişimler olmamakla beraber tüm mevsimlerde pozitif değerlerde saptanmıştır. Sonuçların pozitif olması su kaynağının 
çürütücü yani bozucu ya da paslandırıcı özelliğe sahip olmasıyla açıklanabilir. Ayrıca mevsimsel değişimlerdeki farklılıkların su kaynağının çözünmüş oksijen değerlerindeki değişime bağlı olarak yükseltgenme indirgenme olaylarının gerçekleştiğini göstermektedir.

Klorür iyonu konsantrasyonu doğal sularda genel olarak düşüktür ve su kaynaklarına çözünme yolu ile ya da tuzlu su kaynaklarının tatlı su kaynaklarına karışması sonucu artış göstermektedir. Su kaynaklarında farklı bileşikler halinde özellikle sodyum klorür, kalsiyum ve magnezyum klorür şeklindedir (Geldiay ve Kocataş, 1988; Şengül ve Türkman, 1998). Tuzlu su girişinin ve kirlenmenin olmadığı su kaynaklarında klorür konsantrasyonu 10-20 $\mathrm{mg} \mathrm{L}^{-1}$ arasında değişiklik gösterir (Çağlar ve Saler, 2014). Çalışmada, Karasu Çayı'nın Klorür iyonu konsantrasyonu minimum kış mevsiminde $0.04 \mathrm{~g} \mathrm{~L}^{-1}$ ile 4 . istasyonda ve maksimum sonbahar mevsiminde $0.46 \mathrm{~g} \mathrm{~L}^{-1}$ ile 1 . İstasyonda belirlenmiştir (Çizelge 1). En yüksek değerin 1.istasyonda belirlenmesi, istasyonun deniz ile bağlantısının olmasındandır. Ayrıca su kaynağının mevsimsel Klorür değerlerinde dalgalanmalar, su sıcaklığının artması ile kar sularının erimesi ve mevsimsel yağış miktarlarındaki artışlardan kaynaklanmaktadır. Daha önce gerçekleştirilen çalışmalarda; Çağlar ve Saler (2014), Erzincan Koçan Şelalesinde Klorür derişimini 0.90-1.11 $\mathrm{mg} \mathrm{L}^{-1}$ aralığında olduğunu; Günşen ve ark. (2000), Uludağ'daki su kaynakları ile ilgili çalışmada Klorür derişiminin ortalama $7.02 \mathrm{mg} \mathrm{L}^{-1}$ olduğunu; Çiçek ve Ertan (2012), Antalya Köprüçay Nehri'nde yapmış oldukları çalışmada Klorür derişimini $68.52 \mathrm{mg} \mathrm{L}^{-1}$ olarak tespit etmişlerdir.

Çizelge 3. Karasu Çayı koliform bakterileri ile fizikokimyasal parametre değerleri arasındaki korelasyon

Table 3. Correlation between Karasu Stream coliform bacteria and physicochemical parameter values

\begin{tabular}{|c|c|c|c|c|c|c|c|}
\hline & T.Koliform & F.Koliform & Sıcaklık & $\mathrm{CO}_{2}$ & pH & Alkalinite & ÇO \\
\hline F.Koliform & $0.994 * * *$ & & & & & & \\
\hline Sıcaklık & $0.824 * * *$ & $0.804 * * *$ & & & & & \\
\hline $\mathrm{CO}_{2}$ & $0.381 * *$ & $0.375^{* *}$ & $0.607 * * *$ & & & & \\
\hline pH & $0.794 * * *$ & $0.791 * * *$ & $0.789 * * *$ & 0.086 & & & \\
\hline Alkalinite & $0.697 * * *$ & $0.683 * * *$ & $0.968 * * *$ & $0.663 * * *$ & $0.674 * * *$ & & \\
\hline ÇO & $-0.939 * * *$ & $-0.932 * * *$ & $-0.930 * * *$ & -0.397 & $-0.877 * * *$ & $-0.839 * * *$ & \\
\hline İletkenlik & -0.049 & -0.067 & $-0.300 *$ & -0.115 & -0.165 & $-0.435 * *$ & 0.170 \\
\hline ORP & $-0.903 * * *$ & $-0.892 * * *$ & $-0.941 * * *$ & $-0.402 * *$ & $-0.853 * * *$ & $-0.868 * * *$ & $0.986 * * *$ \\
\hline Klorür & $0.648 * * *$ & $0.632 * * *$ & $0.320 *$ & -0.145 & $0.548 * * *$ & 0.136 & $-0.530 * * *$ \\
\hline $\mathrm{BOl}_{5}$ & -0.142 & -0.120 & -0.237 & $-0.485^{* * *}$ & 0.187 & $-0.329 *$ & 0.122 \\
\hline $\mathrm{NH}_{4}^{-}-\mathrm{N}$ & $0.579 * * *$ & $0.558 * * *$ & $0.575^{* * *}$ & $0.733^{* * *}$ & 0.197 & $0.543 * * *$ & $-0.497 * * *$ \\
\hline $\mathrm{H}_{2} \mathrm{~S}$ & $0.720 * * *$ & $0.706 * * *$ & $0.911^{* * *}$ & $0.310^{*}$ & $0.825^{* * *}$ & $0.908 * * *$ & $-0.878 * * *$ \\
\hline OM & $0.819 * * *$ & $0.787^{* * *}$ & $0.912 * * *$ & $0.476 * * *$ & $0.719 * * *$ & $0.857 * * *$ & $-0.896 * * *$ \\
\hline \multirow[t]{2}{*}{ TAKM } & $0.489 * * *$ & $0.466 * *$ & $0.627 * * *$ & $0.464 * * *$ & $0.297^{*}$ & $0.621 * * *$ & $-0.579 * * *$ \\
\hline & iletkenlik & ORP & Klorür & $\mathrm{BOI}_{5}$ & $\mathrm{NH}_{4}{ }^{-}-\mathrm{N}$ & $\mathrm{H}_{2} \mathrm{~S}$ & OM \\
\hline ORP & 0.265 & & & & & & \\
\hline Klorür & $0.318^{*}$ & $-0.475 * * *$ & & & & & \\
\hline $\mathrm{BOl}_{5}$ & 0.139 & 0.194 & 0.108 & & & & \\
\hline $\mathrm{NH}_{4}^{-}-\mathrm{N}$ & 0.154 & $-0.484 * * *$ & $0.299 *$ & $-0.492 * * *$ & & & \\
\hline $\mathrm{H}_{2} \mathrm{~S}$ & $-0.487^{* * *}$ & $-0.913 * * *$ & $0.292^{*}$ & -0.194 & $0.293^{*}$ & & \\
\hline OM & -0.222 & $-0.894 * * *$ & $0.376 * *$ & -0.220 & $0.567 * * *$ & $0.865^{* * *}$ & \\
\hline TAKM & -0.186 & $0.633^{* * *}$ & 0.120 & $-0.308^{*}$ & $0.675 * * *$ & $0.523 * * *$ & $0.652 * * *$ \\
\hline
\end{tabular}

$P \geq 0.05 ;(*) P \leq 0.05 ;(* *) P \leq 0.01 ;(* * *) P \leq 0.001$

$\mathrm{BOI}_{5}$, bakterilerin aerobik koşullar altında OM'yi ayrıştırmak için kullandığı oksijen miktarıdır (Egemen ve Sunlu, 1996), değeri farklı bölgelerdeki birçok araştırmacı tarafından değerlendirilmiştir. Verep ve ark. (2005), Dinçer (2014) ve Gedik ve ark. (2010) tarafından $\mathrm{BOI}_{5}$ değerleri sırasıyla; Trabzon İyidere'de ortalama 2.40 mg L L ${ }^{-1}$, Rize firtına Deresi'nde $1.85 \mathrm{mg} \mathrm{L}^{-1}$ ve Giresun Çanakçı Deresi'nde $3.83 \mathrm{mg} \mathrm{L}^{-1}$ olarak tespit edilmiştir. Karasu Çayı $\mathrm{BOI}_{5}$ değeri minimum $0.33 \mathrm{mg} \mathrm{L}^{-1}$ (1.ist) ve maksimum $3.61 \mathrm{mg} \mathrm{L^{-1 }}$ (4.ist.) belirlenmiş olup, bulgularımız ile yapılan diğer akarsu çalışmalardaki değerler arasında paralellik bulunmaktadır. Ayrıca $\mathrm{BOI}_{5}$ açısından Yerüstü Su Kalitesi Yönetmeliği ile karşılaştırıldığında I.-II. Sınıf olarak değerlendirilmiştir. Derenin mevsimsel $\mathrm{BOI}_{5}$ değerleri incelendiğinde, $\mathrm{BOI}_{5}$ değerlerinin yaz aylarında düşük ve sonbaharda yüksek olduğu belirlenmiştir. Bu durum, gazların çözünürlüğünün sıcaklık ile ters orantılı olduğu ve sıcaklık arttıkça ÇO değerinin azaldığının göstergesi olarak yorumlanabilir. Yaz aylarında yüksek sıcaklıklar 
nedeniyle, ÇO değerindeki azalma ve aerobik ortamda çalışan bakterilerin azalması veya organik parçalanma sürecinin yavaşlaması ve azalması neden olarak gösterilebilir. Sonbaharda $\mathrm{BOI}_{5}$ değerlerindeki artış; su sıcaklığındaki azalma ve yağıştaki artış nedeniyle artan ÇO miktarı ile açıklanabilir. Su sıcaklığı, suda yaşayan organizmaların optimal yaşam koşullarını ve birçok biyokimyasal süreci etkileyen bir parametredir. Ayrıca çözünmüş oksijeni ve su ortamlarındaki birçok fizikokimyasal özelliği doğrudan değiştirmektedir (Hasançavuşoğlu ve Gündoğdu, 2019).

Karasu Çayı $\mathrm{NH}_{4}{ }^{+} \mathrm{N}$ değerleri incelendiğinde; minimum değer $\left(0.000 \mathrm{mg} \mathrm{L}^{-1}\right)$ sonbaharda 3.ist.'da, maksimum değer (0.32 $\left.\mathrm{mg} \mathrm{L}^{-1}\right)$ illkbaharda 1.ist'da bulunmuştur. Amonyum, sucul ortamda yaşamın sürekliliğini sağlayan besinlerden biridir. Buna rağmen, su kaynaklarında aşırı miktarda bulunduğu takdirde besin kirliliğine neden olmaktadır. Sudaki alglerin çoğalmasını ve büyümesini sağlamanın yanı sıra, su ekosistemindeki ço miktarını azaltarak, sucul canlılar için olumsuz koşulların ve etkilerin ortaya çıkmasına neden olmaktadır (Hasançavuşoğlu ve Gündoğdu, 2019). Su kaynağındaki $\mathrm{NH}_{4}{ }^{+}-\mathrm{N}$ değerlerinin sonbahar ve kış mevsimlerinde düşük olduğu saptanmıştır. Bunun nedeni; düşük su sıcaklıkları sebebiyle çO miktarı artmakta ve nitrifikasyon olayları hızlanmaktadır. $\mathrm{NH}_{4}$ bu mevsimlerde oksitlenerek $\mathrm{NO}_{2}{ }^{-}$ve $\mathrm{NO}_{3}{ }^{-}$'e dönüşmektedir. $\mathrm{Bu}$ döngüde $\mathrm{NH}_{4}$ kullanıldığından azalma eğilimi göstermektedir. Kıvrak ve ark. (2012) tarafından Afyon Akarçay'da yapılan çalışmada 0.11$20.04 \mathrm{mg} \mathrm{L}^{-1} \quad \mathrm{NH}_{4}{ }^{+}-\mathrm{N}$; Taşdemir ve Göksu (2001) tarafından Asi Nehri'nde yapılan çalışmada ise 0.02-1.98 $\mathrm{mg} \mathrm{\textrm {L } ^ { - 1 }} \mathrm{NH}_{4}{ }^{+}-\mathrm{N}$ konsantrasyonları belirlenmiştir. $\mathrm{Bu}$ sonuçların çalışmamızdaki $\mathrm{NH}_{4}{ }^{+}-\mathrm{N}$ sonuçları ile uyumlu olduğu bulunmuştur. Kıtaiçi Yerüstü Su Kaynaklarının Genel Kimyasal ve Fizikokimyasal Parametreler Açısından Sınıflarına Göre Kalite Kriterleri ile karşılaştırıldığında (Çizelge 4), Karasu Çayı́nda su kalitesi $\mathrm{NH}_{4}{ }^{+}-\mathrm{N}$ değerleri açısından I.-II. Sınıf (yüksek kaliteli su) bulunmuştur (Anonim, 2016).

$\mathrm{H}_{2} \mathrm{~S}$, normal koşullar altında renksiz, toksik, uçucu ve yanıcı bir gazdır. Su kaynaklarındaki $\mathrm{SO}_{4}{ }^{-2}$ iyonu, anaerobik ortamlarda sülfat azaltıcı mikroorganizmalar tarafından oksijen kaynağı olarak kullanılır ve biyokimyasal reaksiyonların sonucu olarak $\mathrm{S}^{-2}$ iyonu oluşur. $\mathrm{S}^{-2}$ iyonu, $\mathrm{H}_{2} \mathrm{~S}$ gazı oluşturmak için su içindeki hidrojen ile reaksiyona girer. Çalışmada, su kaynağındaki $\mathrm{H}_{2} \mathrm{~S}$ değerleri incelendiğinde, yaz aylarında değerlerin yüksek olduğu görülmektedir (Çizelge 1). Bunun nedeni, su sıcaklıklarındaki mevsimsel artışın ÇO miktarını azaltmasıdır. Bu nedenle oksijensiz ortamda organik bozunma, anaerobik bakteriler tarafından gerçekleştirilir ve dolayısı ile oksijensiz ürünlerin oluşumu artmaktadır (Egemen ve Sunlu, 1996; Öztürk, 2006). Diğer mevsimlerde $\mathrm{H}_{2} \mathrm{~S}$ değerlerinin daha düşük olmasının nedeni sıcaklıkla ilişkilendirilebilir. Bu durum su sıcaklığındaki değişiklikler nedeniyle çO değerinin artması ve aerobik koşullarda oksijenli ürünlerin meydana gelmesi ile açıklanabilir. $\mathrm{S}^{-2}$ döngüsünün son aşaması $\mathrm{SO}_{4}{ }^{-2}$ olduğundan, sülfürün büyük bir kısmının, çözünmüş oksijenin artmasıyla sülfata dönüşmesi mümkündür. $\mathrm{H}_{2} \mathrm{~S}$ korelasyon değerlerinin sıcaklık, $\mathrm{NH}_{4}$ ve OM ile doğru orantılı (sırasıyla $r=0.911, r=0.293$ : $P \leq 0.05$; $r=0.865, P \leq 0.001$ ), ÇO, iletkenlik ve ORP ile ters orantılı (sırasıyla $r=-0.878, r=-0.487, r=-0.913 ; P \leq 0.001$ ) olduğu belirlenmiştir (Çizelge 3).

Araştırma sonuçları dikkate alındığında OM'nin minimum değerlerinin sonbahar, kış aylarında ve maksimum değerlerinin yaz aylarında olduğu belirlenmiştir (Çizelge 2). Akarsuyun OM değerleri 0.27$481.33 \mathrm{mg} \mathrm{L}^{-1}$ arasında değişmektedir. Gedik ve ark.'nın (2010) Rize Fırtına Deresi'nde ve Dinçer'in (2014) Giresun Çanakçı Deresi'nde yapmış oldukları çalışmadan elde ettikleri OM değerlerinin, Karasu Çayı'nda bulduğumuz sonuçlardan farklı olduğu belirlenmiştir. Çalışmamızdaki OM miktarlarındaki dalgalanmalar ve diğer araştırmalarla benzerlik göstermemesi mevsimsel sıcaklık farklılıklarının olmasıyla, $\mathrm{pH}$, yağış değişiklikleri ve bölgesel farklılıklarla açıklanabilir. OM korelasyon değerleri incelendiğinde (Çizelge 3), sıcaklık, $\mathrm{pH}, \mathrm{NH}_{4}$ ve TAKM ile doğru orantılı olduğu (sırasıyla $r=0.912$, $r=0.719, r=0.567$ ve $r=0.652$ ) ve istatistiksel olarak anlamlı olduğu bulunmuştur $(P \leq 0.001)$.

Askıda katı maddeler sular için önemli bir parametredir; sudaki katı madde miktarı arttıkça, suyun geçirgenliği azalır ve katı maddeler sudaki organizmalar için olumsuz koşullara neden olmaktadır (Dihkan ve ark., 2011). TAKM, suda çözünen ve çözünmeyen katıların toplamı olarak bilinir. Genellikle kolloidal organik maddeler, tortu malzemeleri, çamur veya kil minerallerinden oluşmaktadır (Uslu ve Türkman, 1987). Taşdemir ve Göksu (2001) Asi Nehri'nde TAKM değerini mg L-1 değerleri arasında, Tepe ve Mutlu (2004) Hatay Harbiye Kaynak suyunda TAKM değerini ortalama $1.75 \mathrm{mg} \mathrm{L}^{-1}$ olarak bulmuşlardır. Çalışmamızda TAKM değerleri literatür çalışmalarına göre daha düşük değerlerde belirlenmiştir (Çizelge 1). İstatistik olarak farklılıklar önemli olmamakla birlikte TAKM değerleri mevsimsel değişikliklerde artış ve azalış göstermiş olup, bunun su akış hızı ve yağış miktarı ile bağlantılı olduğu sonucuna varılmıştır. Yaz mevsiminde TAKM değerlerinin diğer mevsimlere göre daha yüksek olması buharlaşmanın ve kentsel atık su girdisinin yüksek olmasıdır. TAKM 'nin korelasyon değerlerinin çO ile ters orantılı olduğu ( $r=-$ $0.579, P \leq 0.001$ ) ve sıcaklık, $\mathrm{NH}_{4}, \mathrm{pH}$, ile doğru orantılı olduğu (sırasıyla $r=0.627, r=0.675: P \leq 0.001 ; r=0.297: P$ $\leq 0.01$ ) bulunmuş olup, istatistiksel açıdan önemli olduğu saptanmıştır (Çizelge 3). Kıtaiçi Yerüstü Su Kaynaklarının 
Genel Kimyasal ve Fizikokimyasal Parametreler Açısından Sınıflarına Göre Kalite Kriterleri'ne göre; akarsuyun TAKM değerleri I. Sınıf (Çizelge 4) su kalitesindedir (Anonim, 2016).

Koliformlar çok çeşitli bakteri türleridir. Enterobacteriaceae familyasındaki koliform grubu; çubuk şeklinde, spor oluşturmayan, laktozun 48 saatte $35^{\circ} \mathrm{C}$ 'de fermantasyonuyla gram negatif gaz üreten bakterilerdir. Koliform bakterileri en çok hayvanların bağırsaklarında, ayrıca bitkilerde ve toprakta görülmektedir (Halkman 2005; Şengül ve Türkman, 1998). Su kaynaklarında F. koliform bakterilerinin varlığı, suyun dışkı atıklarıyla temas halinde olduğunu göstermektedir. Bu durum su kaynaklarının birçok zararlı, tehlikeli ve hastalığa neden olan bakteri, protozoa, parazit ve virüslerle kirlendiğinin göstergesidir
(Halkman, 2005). Karasu Çayı T. koliform ve F. koliform'un minimum değerleri sırasıyla 32.88 ve 24.88 kob $100^{-1} \mathrm{ml}^{-1}$ ile 4.ist.'da ve maksimum değerleri sırasıyla 721.22 ve 627.33 kob $100^{-1} \mathrm{ml}^{-1}$ ile 1 .ist.'da tespit edilmiştir. Dicle nehri'ndeki koliform miktarı 2.10$4.02 \log 10$ kob $100^{-1} \mathrm{ml}^{-1}$ (Vural ve Erkan, 2006) olarak bulunmuş olup, Bitlis ilinin içme suyunda koliform ve $E$. coli miktarının 501-5000 100-1 $\mathrm{ml}^{-1}$ aralığında olduğu hesaplanmıştır (Alemdar ve ark., 2009). Çanakkale Sarıçay Deresi ve Kahramanmaraş Aksu Deresi'nde Çolakoğlu ve Çakır (2003) ve Toroğlu ve ark. (2006) tarafından F. koliform yükü >1100 $100^{-1} \mathrm{ml}^{-1}$ olarak bulunmuştur. Koliform değerlerinin diğer çalışmaların sonuçlarından farklı olması yer ve zaman farkından kaynaklanmaktadır.

Çizelge 4. Karasu Çayı Su Kalite Parametrelerinin Yerüstü Su Kalitesi Yönetmeliğine göre değerlendirilmesi

Table 4. Evaluation of Karasu Stream Water Quality Parameters according to the Surface Water Quality Regulation

\begin{tabular}{|c|c|c|c|c|}
\hline \multirow{2}{*}{ Parametreler } & \multicolumn{4}{|c|}{ Su Kalitesi Sınıfları } \\
\hline & I. & II. & III. & IV. \\
\hline Sıcaklık & $x$ & & & $x$ \\
\hline pH & $x$ & $x$ & & \\
\hline ÇO & & $x$ & & $x$ \\
\hline İletkenlik & $x$ & & & \\
\hline Klorür & $x$ & & & \\
\hline $\mathrm{BOl}_{5}$ & $x$ & $x$ & & \\
\hline $\mathrm{NH}_{4}^{-}-\mathrm{N}$ & $x$ & $x$ & & \\
\hline $\mathrm{H}_{2} \mathrm{~S}$ & & & & $x$ \\
\hline OM & $X$ & & & $x$ \\
\hline TAKM & $X$ & & & \\
\hline T.Koliform & $x$ & $x$ & & \\
\hline F.Koliform & & $x$ & $x$ & \\
\hline
\end{tabular}

Sınıf I: Temiz. Sınıf II Az kirli. Sınıf III: Kirli ve Sınıf IV: Çok kirli.

F. koliform'un mevsimsel değişiminin T. koliform ile paralel olduğu belirlenmiştir. T. koliform'ların çoğunun genellikle sularda gözlenmesi istenmeyen $F$. koliformlardan oluştuğu görülmektedir. Bu durum derenin yıl boyunca insan ve hayvan dışkısı ile temas halinde olduğunun bir göstergesidir. Akarsu'daki T. koliform ve F. koliform yükünün yaz aylarında diğer mevsimlere göre daha yüksek olduğu tespit edilmiştir. Koliform konsantrasyonlarının artmasının nedenleri; mevsimsel sıcaklık değişimi, mikroorganizmalar için uygun üreme ortamının oluşumu, mevsimsel yağış miktarının azalması ve turizm nedeni ile nüfus artışına paralel olarak kanalizasyonlardaki atık yükünün artışıdır. Yazdan kışa geçişte, T. koliform ve $F$. koliform değerlerindeki azalmaya; su sıcaklığındaki düşüş, atık yüklerindeki azalma ve yağışlardaki artış neden olmuştur. T. koliform ve F. koliform değerinin tüm mevsimlerde 1.ist.'da maksimum olduğu bulunmuştur. Bunun nedeni 1.ist.'un hayvanların güzergahının üzerinde olmasıdır. T. Koliform korelasyon sonuçları değerlendirildiğinde ÇO ve ORP ile ters orantılı olduğu ( $r=-0.939$ ve $r=-0.903$ ), F. Koliform, sıcaklık, $\mathrm{pH}, \mathrm{NH}_{4}, \mathrm{H}_{2} \mathrm{~S}$, OM ve TAKM ile doğru orantılı olduğu (sırasıyla $r=0.994$, $r=0.824, r=0.794, r=0.579, r=0.720, r=0.819$ ve $r=0.489$ ) belirlenmiş olup ( $P \leq 0.001)$, istatistiksel açıdan oldukça önemli olduğu tespit edilmiştir. Çizelge 3 'te görüldüğü üzere F. Koliform korelasyon değerlerinin parametrelerle aynı doğrultuda istatistiksel açıdan bağlantılı olduğu saptanmıştır. Fiziksel parametrelerin ve koliformların ortalama değerleri "Yerüstü Su Kalitesi Yönetmeliği" Kıtaiçi Yerüstü Su Kaynaklarının Sınıflarına Göre Kalite Kriterleri'ne göre değerlendirildiğinde, Karasu Çayı'nın ÇO bakımından az ya da çok kirli (II.-IV. Sınıf), $\mathrm{H}_{2} \mathrm{~S}$ açısından çok kirli (IV. Sınıf), T. koliform (I.-II. Sınıf) ve F. koliform açısından az kirli-kirli (II.-III. Sınıf) olduğu belirlenmiştir (Çizelge 4; Anonim, 2015a; Anonim, 2016). 
Gelişen dünyada çevreye olan duyarlılığın artmasına bağlı olarak su kirliliği konusunda gereken önlemler alınmaya çalışısa da yeterli olmadığı bilinmektedir. Su kaynaklarının kalite ve kirlilikleri üzerinde yapılan çalışmaların artması ve su kaynaklarının şu anki durumları ile kirletici kaynaklarının belirlenmesi çok önem arz etmektedir. Karasu çayı sularını denize ulaştırana kadar yerleşim yeri ve tarım arazilerinden geçmektedir. Su kaynağının su kalite parametrelerinin mevcut durumlarının iyileştirilmemesi, korunamaması ve ilerleyen yıllarda kirlilik yükünün artması sonucu ekosisteminde ve su havzasında sucul yaşam ile insan sağlığını etkileyecek durumların ortaya çıkması mümkündür.

Çalışmada elde edilen veriler değerlendirildiğinde, su kaynağının ÇO değerinin düşük ve $\mathrm{H}_{2} \mathrm{~S}, \mathrm{~T}$. Koliform ve $\mathrm{F}$. Koliform değerlerinin yüksek değerlerde seyrettiği belirlenmiştir. Bu durum su kaynağında ötrofikasyonun başlamasına ya da artışına sebep olabilme intimalini güçlendirmektedir. Su kaynağındaki çözünmüş oksijen değerlerinin düşük çıkmasında, askıda katı madde miktarının, sıcaklığın, organik madde yükünün ve diğer kirleticilerin etkisi olduğu düşünülebilir. Bu parametrelerin kontrol altına alınması ve sürekli izlenmesi çözünmüş oksijen değerinin de doğal olarak normal değerlere geri dönebileceği intimalini desteklemektedir. Çalışmamızda ortaya çıkan kirlilik türlerinden biri olan Hidrojen sülfür kirliliği için alınabilecek önlemlerin başında su kaynakları çevresindeki yerleşim bölgelerinin kanalizasyon alt yapılarının düzeltilmesi ve atık suların su kaynaklarına verilmeden önce organik madde yükünün azaltılmasına yönelik tedbirlerin alınması gerekmektedir. Koliform kirliliğinin temel kaynağı kanalizasyon kökenli atık sular oluşturmaktadır. Bu bakteriler insan sağlığı için ciddi boyutları olan hastalıklara sebep olabilmektedir. Su kaynağının Koliform yükünün sürekli izlenmesi ve kanalizasyon deşarj sistemlerinin kurulması ile kirliliğin önlenmesinde etkili olabileceği söylenebilir. Karasu çayı'nın mevcut durumunun periyodik aralıklarla izlenmesi, iyileştirilmesi ve korunması için gereken tedbirlerin alınması gerekmektedir. Bunun yanında su kaynağının çevresindeki yerleşim bölgelerinden ve tarım arazilerinden su kaynaklarına giriş yapan askıda katı madde yükünün artmasına sebep olabilecek maddelerinde kontrol altında tutulması gerekmektedir.

Su kaynaklarının sürdürülebilirliklerini sağlayabilmek; sucul ortamların daha fazla bozulmalarının engellenmesi ve iyileştirilmeleri, su kaynaklarının uzun vadeli korunarak kullanımlarının sağlanması, konunun ciddiyetinin ve öneminin daha fazla ön plana çıkarılmasıyla mümkün olabilir. Avrupa birliği su çerçeve direktifinin ana hedefi olan, nehir havzası bazında yönetim kavramının yaygınlaştırılması sağlanmalıdır. Sucul canlılar için yaşam kalitesi ve neslin sürdürebilirliği doğal suların kaliteli ve temiz olması ile mümkün olacaktır.

\section{ÖZET}

Amaç: Kentleşmenin ve sosyoekonomik faaliyetlerin her geçen gün artması, evrende doğal kaynakların kirlenmesine ve bozulmasına neden olmaktadır. Çalışma, Karadeniz Bölgesi'ndeki Küre Dağları'nın Gündüzlü Ormanlarından doğan ve Sinop'un $8 \mathrm{~km}$ batısındaki Akliman sahilinden Karadeniz'e dökülen Karasu Çayı'nın su kalitesini belirlemek amacıyla yapılmıştır.

Yöntem ve Bulgular: Karasu Çayı'nın sıcaklık, karbondioksit, $\mathrm{pH}$, alkalinite, çözünmüş oksijen, iletkenlik, oksidasyon-redüksiyon potansiyeli, klorür, biyolojik oksijen ihtiyacl, amonyum azotu, hidrojen sülfür, organik madde, toplam askıda katı madde parametreleri ile Toplam koliform ve Fekal koliform değerleri Mayıs 2014'ten Nisan 2015'e kadar her ay takip edilerek mevsimsel durumu ortaya konulmuştur. Karasu Çayı'nın Toplam koliform ve Fekal koliform yükü en düşük kış mevsiminde (4. istasyon), en yüksek yaz mevsiminde (1. istasyon) tespit edilmiştir. Su örneklerinin analizi $\mathrm{BOI}_{5}, \mathrm{NH}_{4}{ }^{+}-\mathrm{N}, \mathrm{OM}$, Toplam koliform ve Fekal koliform ortalama değerlerinin mevsimler ve istasyonlar arasında istatistiksel farklılıkları anlamlı $(P$ $<0.05)$ bulunmuştur. Ayrıca sıcaklık, $\mathrm{CO}_{2}, \mathrm{pH}$, ÇO, alkalinite ve $\mathrm{H}_{2} \mathrm{~S}$ değerleri mevsimler arası önemli ölçüde farklılık gösterirken $(P<0.05)$, istasyonlar arası farklılık ( $P$ $>0.05$ ) olmamıştır.

Genel Yorum: Araştırma sonuçları Yerüstü Su Kalitesi Yönetmeliği ile karşılaştırıldığında nehir suyunun Toplam koliform (I.-II. Sınıf) ve Fekal koliform (II.-III. Sınıf) yükünün sınıfları belirlenmiştir. Su kaynağının çO değerinin düşük ve $\mathrm{H}_{2} \mathrm{~S}$, F. Koliform değerlerinin yüksek değerlerde seyrettiği belirlenmiştir. Bu durumun su kaynağında ötrofikasyonun başlamasına ya da artışına sebep olabilme ihtimalini güçlendirmektedir.

Çalışmanın Önemi ve Etkisi: Su kaynaklarının sürdürülebilirliklerini sağlayabilmek için, sucul ortamların daha fazla bozulmalarının engellenmesi gerekmekte ve su kaynaklarının korunmasının sağlanması, konunun ön plana çıkarılmasıyla mümkün olabilir.

Anahtar Kelimeler: Koliform, dere, nehir, kirlilik, su kalitesi, Karasu Çayı, Karadeniz. 


\section{TEŞEKKÜR}

Çalışma, "Karasu Çayı ve Sırakaraağaçlar Deresi'nde Bazı Fiziko-Kimyasal ve Mikrobiyolojik Parametrelerin Araştırılması" adlı Sinop Üniversitesi Fen Bilimleri Enstitüsü Yüksek Lisans Tez verilerinden üretilmiştir.

\section{ÇIKAR ÇATIŞMA BEYANI}

Yazarlar çalışma konusunda çıkar çatışmasının olmadığını beyan etmektedir.

\section{ARAŞTIRMACILARIN KATKI ORANI BEYANI}

Yazarlar çalışmaya eşit oranda katkı sağlamış olduklarını beyan eder.

\section{KAYNAKLAR}

Abreu-Acosta N, Vera L (2011) Occurence and removal of parasites, enteric bacteria and faecal contamination indicators in wastewater natural reclamation systems in Tenerife- Canary Islands, Spain, Ecological Engineering, 37: 496-503.

Acehan G (2007) İçme Sularının Mikrobiyolojik Kirlenme Potansiyelinin İncelenmesi. Yüksek Lisans Tezi, Çukurova Üni. Fen Bil. Ens., Adana, 235s.

Aksu H (2004) İçme Suyu Kaynaklı Mikrobiyolojik Risklerin Değerlendirilmesi. İstanbul ve Su Sempozyumu: Tartışmalar ve Forum, Ocak 8-9, İstanbul, Türkiye.

Al-Bahry S, Mahmoud IY, Al-Belushi KIA, Elshafie AE, AlHarthy A, Bakheit CK (2009). Coastal sewage discharge and its impact on fish with reference to antibiotic resistant enteric bacteria and enteric pathogens as bio-indicators of pollution. Chemosphere, 77: 1534-1539.

Alemdar S, Kahraman T, Ağaoğlu S, Alişarlı M (2009) Bitlis ilii İçme Sularının Bazı Mikrobiyolojik ve Fizikokimyasal Özellikleri. Ekoloji, 19 (73): 29-38.

Anonymous (1997a) Guidelines For Drinking Water Quality. Health Criteria and Other Supporting Information, Second ed., World Health Organization (WHO), Geneva, 2: 65.

Anonymous (1997b) Volunteer Stream Monitoring: A Methods Manual. United States Environmental Protection Agency (USEPA), Office of Water 4503F, EPA 841-B-97-003, Washington.
Anonymous (2000) Directive 2000/60/EC (European Commission) of the European Parliament and of the Council of 23 October 2000. Establishing a framework for community action in the field of water policy. Official Journal of the European Communities I. 327: 1-73. http://eurlex.europa.eu/resource.html?uri=cellar:5c835afb2ec6-4577-bdf8756d3d694eeb.0004.02/DOC 1\&format=PDF (Erişim Tarihi: 20 Ekim 2017).

Anonim (2015a) Yüzeysel Su Kalitesi Yönetimi Yönetmeliğinde Değişiklik Yapılmasına Dair Yönetmelik (YSKY). Resmi Gazete: 29327. http://www.resmigazete.gov.tr/eskiler/2015/04/201 50415-18.htm (Erişim Tarihi: 04 Nisan 2018)

Anonim (2015b) Yer Üstü Suları, Yer Altı Suları ve Sedimentten Numune Alma ve Biyolojik Örnekleme Tebliği. Resmi Gazete: 29274. https://kms.kaysis.gov.tr/(X(1)S(zcngcuaclmhulefyex uka4c0))/Home/Goster/44298?AspxAutoDetectCook ieSupport=1 (Erişim Tarihi: 24 Haziran 2020).

Anonim (2015c) Yüzeysel Su Kalitesi Yönetimi Yönetmeliğinde Değişiklik Yapılmasına Dair Yönetmelik (YSKY). Resmi Gazete: 29327. http://www.resmigazete.gov.tr/eskiler/2015/04/201 50415-18.htm (Erişim Tarihi: 04 Nisan 2018).

Anonim (2016a) T.C. Çevre ve Şehircilik Bakanlığ, Sinop Valiliği Çevre ve Şehircilik il Müdürlüğü, Sinop ili 2015 Yılı Çevre Durum Raporu (2016). https://webdosya.csb.gov.tr/db/ced/editordosya/Si nop2015.pdf (Erişim Tarihi: 10 Temmuz 2020).

Anonim (2016b) Yerüstü Su Kalitesi Yönetmeliği (YSKY). Resmi Gazete Sayl: 29797. http://www.resmigazete.gov.tr/eskiler/2016/08/201 60810-9.htm (Erişim Tarihi: 22 Nisan 2018).

Anonim (2018) World Health Organization (WHO). Diarrhoeal Disease. http://www.who.int/newsroom/factsheets/detail/diarrhoeal-disease (Erişim Tarihi: 22 Temmuz 2018).

APHA (1999) American Public Health Association. Standard Methods for the Examination of Water and Wastewater. (Eds. Rice EW, Baird RB, Eaton AD, and Clesceri LS). 20th ed. American Public Health Association, American Water Works, Association and the Water Environment Federation. Washington, DC. Augustyn L, Babula A, Joniec J, Stanek-Tarkowska J, Hajduk E, Kaniuczak J (2016) Microbiological Indicators of the Quality of River Water, Used for Drinking Water Supply. Polish J. Environ. Studies, 25(2): 511-519. 
Ayaz E (2015) Samsun ve Giresun illerinden Alınan Su Örneklerinde Cryptosporidium parvum'un Moleküler Teknikler Kullanılarak Tespit Edilmesi. Yüksek Lisans Tezi, Ordu Üni., Fen Bil. Ens., Ordu. $155 \mathrm{~s}$.

Berber i, Avşar C (2014) Investigating Some Microbial Pollution Parameters of Seawater and Mussels (Mytilus galloprovincialis, Lamarck 1819) of Sinop. Black Sea Coastal Zone, Turkey. Sains Malaysiana, 43(12), 1835-1842.

Bogdal A, Kowalik T, Ostrowski K, Skowron P (2016) Seasonal variability of physicochemical parameters of water quality on length of Uszwica river. J. Eco. Engin. 17(1): 161-170.

Boyd CE (1995) Bottom Soils, Sediment and Pond Aquaculture, Chapman \& Hall, New York, USA.

Bulut C, Akçimen U, Uysal K, Küçükkara R, Savaşer S, Tokatlı C, Öztürk GN, Köse E (2012) Kestel Deresi (Burdur) Su Kalitesinin Belirlenmesi ve Alabalık Yetiştirciliği Açısından Değerlendirilmesi. Dumlupınar Üni., Fen Bil. Ens. Derg. 28: 1-10.

Burres E (2009) Surface water ambient monitoring program using IDEXX for fecal indicator bacteria monitoring. SWRCB-Clean Water Team, Canada.

Cirik S, Cirik Ş (2008) Limnoloji. Ege Üniversitesi Su Ürünleri Fakültesi Yayınları, İzmir, 166s.

Çağlar M, Saler S (2014) Koçan Şelalesi (Erzincan)'nin Bazı Fiziksel ve Kimyasal Su Kalitesi Özellikleri. Yunus Araştırma Bülteni, 3: 37-42.

Çarlı U (2015) Karasu Çayı ve Sırakaraağaçlar Deresi'nde bazı fiziko-kimyasal ve mikrobiyolojik parametrelerin araştırılması. Yüksek Lisans Tezi, Sinop Üni., Fen Bil. Ens. Sinop, 136s.

Çiçek NL, Ertan ÖO (2012) Köprüçay Nehri (Antalya)'nin Fiziko-Kimyasal Özelliklerine Göre Su Kalitesinin Belirlenmesi. Ekoloji, 21(84): 54-65.

Çolakoğlu FA, Çakır F (2003) Sarıçay Akarsuyunun Mikrobiyolojik Kalitesi, Çanakkale Üniversitesi Su Ürünleri Fakültesi, 305-312.

Dihkan M, Karslı F, Güneroğlu A (2011) Karadeniz Kıyı Sularında Askıda Katı Madde Dağılımının Haritalanması. TMMOB Harita ve Kadastro Müh. Odası 13. Türkiye Harita Bilimsel ve Teknik Kurultayı, Ankara.

https://www.hkmo.org.tr/resimler/ekler/61a784657 319a26 ek.pdf (Erişim Tarihi: 22 Temmuz 2018).

Dinçer S (2014) Çanakçı Deresi Su Kalitesi ve Kirlilik Düzeyinin Belirlenmesi. Yüksek lisans Tezi, Giresun Üni. Fen Bil. Ens., Giresun, 73s.

Egemen Ö, Sunlu U (1996) Su Kalitesi, Ege Üniversitesi Su Ürünleri Fakültesi Yayınları, İzmir, 153s.
Elmacı A, Teksoy A, Topaç FO, Özengin N, Başkaya HS (2008) Uluabat Gölünün Mikrobiyolojik Özelliklerinin Mevsimsel Değişiminin İzlenmesi. Uludağ Üni. Mühendislik-Mimarlık Fak. Derg. 13 (1): 93-103.

Elmanama AA, Afifi S, Bahr B (2006) Seasonal and spatial variation in the monitoring parameters of Gaza Beach during 2002-2003, Environ. Res. 101, 25-33.

Er CB (2014) Kilis İçme Sularının Bazı Fizikokimyasal ve Mikrobiyolojik Özellikleri, Yüksek lisans Tezi, Kilis 7 Aralık Üni. Fen Bil. Ens., Kilis, 50s.

Fakir Y (2012) Denizli içme suyu şebekesindeki su kalitesi parametrelerinin zamana ve konuma göre değişiminin incelenmesi. Yüksek Lisans Tezi, Pamukkale Üni., Fen Bil. Ens., İnşaat Müh. ABD, Denizli. 142s.

Gedik K, Verep B, Ertuğrul T, Fevzioğlu S (2010) Fırtına Deresi (Rize)'nin Fiziko-Kimyasal Açıdan Su Kalitesinin Belirlenmesi, Ekoloji, 19(76): 25-35.

Geldiay R, Kocataş A (1988) Deniz Biyolojisine Giriş. Ege Üniversitesi Fen Fakültesi Kitaplar Serisi, İzmir, 459.

Guo T, Delaune RD, PatrıckJr WH (1997). The Effect of Sediment Redox Chemistry on Solubility/Chemically Active Forms of Selected Metals in Bottom Sediment Receiving Produced Water Discharge. Spill, Science\&Technology Bulletin, 4 (3): 165-175.

Gültekin F, Ersoy AF, Hatipoğlu E, Celep S (2012) Determination of Water Quality Parameters in Wet Season of Surface Water in Trabzon. Ecology, 21(82): 77-88.

Gündoğdu A (1995) Sinop Ili Sahilinde Anyonik Deterjan Kirliliğinin Araştırılması. Yüksek lisans Tezi. Ondokuz Mayıs Üniversitesi, Su Ürünleri Yüksek Okulu, Samsun, 60s.

Günşen U, Anar Ş, Gündüz H (2000) Uludağ'daki Su Kaynaklarının Fiziksel, Kimyasal ve Mikrobiyolojik Özellikleri. SDÜ Tıp Fakültesi Dergisi, 7 (2): 21-24.

Gürel E (2011) Porsuk Çayı Su Kalitesinin Belirlenmesi. Yüksek lisans Tezi, Eskişehir Osmangazi Üniversitesi Fen Bilimleri Enstitüsü, Eskişehir, 70s.

Hagendorf U, Diehl K, Feuerpfeıl I, Hummel A, Szewzyzk $R$ (2000) Retention of microbiological organisms in constructed wetlands. In: Proceedings of the Seventh International Conference on Wetland Systems for Water Pollu- tion Control., Gainesville: IWA and University of Floryda, pp 391.

Halkman AK (2005). Gida Mikrobiyolojisi Uygulamaları (Food Microbiology Applications, Başak Typography (Merck., Ed: A. K. Halkman, Başak Matbaacılık), Ankara, Türkiye, 89-124: 358.

Hamzah, A, Kipli SH, Ismail SR, Una R, Sarmani S (2011) Microbiological study in coastal water of Port Dickson. Sains Malaysiana, 40(2), 93-99. 
Hasançavuşoğlu, Z, Gündoğdu A (2019) Investigation of Anionic Detergent Pollution in Sarıkum Lake (Sinop). Turkish Journal of Agriculture - Food Science and Technology, 7(11): 1825-1833.

James CN, Copeland RC, Lytle DA (2004). American Water Works Association, WQTC Conference, 13.

Kanownik W Rajda W (2011) Samooczyszczanie wody potoku Pychowickiego. Zeszyty Problemowe Postepow Nauk Rolniczych, 561: 81-91.

Kara C, Çömlekcioğlu U (2004) Karaçay (Kahramanmaraş)'ın Kirliliğinin Biyolojik ve FizikoKimyasal Parametrelerle Incelenmesi. Kahramanmaraş Sütçü İmam Üniversitesi Fen ve Mühendislik Bilimleri Dergisi, 7(1): 7.

Kıvrak E, Uygun A, Kalyoncu, H (2012) Akarçay'ın (Afyonkarahisar) Su Kalitesini Değerlendirmek İçin Diyatome İndekslerinin Kullanılması. AKÜ FEBID, 12, 27-38.

Kilinc B, Besler A (2014) The occurrence of enteric bacteria in marine environment and pollution. Marine Science and Technology Bulletin, 3(2): 39-43.

Kolören Z, Elif Demirel E, Taş B (2011) Ulugöl (Ordu, Türkiye)'de Fekal Kirlilik İndikatörü Bakterilerin Tespiti. Biyoloji Bil. Araş. Derg. 4(2): 151-156.

Küçük S (2007) Büyük Menderes Nehri Su Kalite Ölçümlerinin Su Ürünler açısından İncelenmesi. Adnan Menderes Üni. Zir. Fak. Derg. 4(1-2): 7- 13.

Leong SS, Ismail J, Nurdiyana A, Denil NA, Shahru, R, Sarbini SR, Wafri Wasli W, Debbie A (2018) Microbiological and Physicochemical Water Quality Assessments of River Water in an Industrial Region of the Northwest Coast of Borneo. Water, 10, 1648.

Lipp EK, Farrah SA, Rose JB (2001) Assesment and Impact of Microbial Fecal Pollution and Human Enteric Pathogens in a Coastal Community. Marina Pollution Bulletin, 42(4): 286-293.

Majedul Islam MM, Hofstra N, Atikul Islam Md. (2017) The Impact of Environmental Variables on Faecal Indicator Bacteria in the Betna River Basin, Bangladesh. Environ. Process, 4:319-332.

Mostafa AH, Al-Wasify, RS, Sayed AM, Haroun BM (2013) Microbiological and physicochemical evaluation of groundwater in Egypt. Int. J. Environ. Sustainability, 2: 1-10.

Napieralska A, Gołdyn R (2013) Sanitary Analyses of Runoff Water a River. Polish J. Environ. Studies, 22(2): 481-486.

Öner O, Celik A (2001) Investigation of some pollution parameters in water and sediment samples collected from the lower Gediz river basin. Ecology, 20(78): 4852.
Öztürk M (2006) Kanalizasyonda Hidrojen Sülfür Gazı Oluşumu ve Sağlık Üzerine Etkileri. Çevre Orman Bakanlığı, Ankara, 13. www.gaosbitfaiye.org/images/fc747691-795c-413da07f-74775e252c5dh2s.pdf (Erişim Tarihi: 04 Nisan 2018).

Salyers AA, Whitt DD (2012) Microbes and a human in imbalance: infectious diseases. In: Microbiology. Diversity, pathogenicity and environment. (Eds. Salyers A, Dixi W) PWN, Warsaw, [In Polish].

Sigua GC, Palhares JCP, Kich JD, Mulinari MR, Mattei RM, Klein JB, Müller S, Plieske G (2010) Microbiological Quality Assessment of Watershed Associated with Animal-Based Agriculture in Santa Catarina, Brazil. Water, Air \& Soil Pollution, 210: 307.

Singh AK, Das S, Singh S, Pradhan N, Gajamer VR, Kumar S, Lepcha YD Tiwari HK (2019) Physicochemical Parameters and Alarming Coliform Count of the Potable Water of Eastern Himalayan State Sikkim: An Indication of Severe Fecal Contamination and Immediate Health Risk. Front. Public Health, 7: 174.

Sigg L (2000) "Redox Potantial Measurements in Natural Waters: Signifigance, Concepts, and Problems" Redox Fundamaentals, Processes and Aplications. (Eds: Schüring J, Schulz HD, Fischer WR, Böttcher J, Duijnisveld MHW). Springer, Berlin, 1-12.

Sukatar A, Yorulmaz B, Ayaz D, Barlas M (2006) Emiralem Deresi'nin (Izmir-Menemen) Bazı Fiziko-Kimyasal ve Biyolojik (Bentik Makroomurgasızlar) Özelliklerinin İncelenmesi. SDÜ Fen Bil. Ens. Derg. 10 (3): 328-333.

Şengül F, Türkman A (1998) Su ve Atıksu Analizleri. TMMOB Çevre Mühendisleri Odası, İzmir, 152s.

Şengün E (2013) Aksu Deresi Su Kalitesi ve Kirlilik Düzeyinin Belirlenmesi. Yüksek Lisans Tezi, Giresun Üni. Fen Bil. Ens., Giresun, 66s.

Taş B, Yavuz Candan A, Can Ö, Topkara S (2010) Ulugöl (ORDU)'nün Bazı Fiziko-Kimyasal Özellikleri. J. Fisheries Sci. 4 (3): 254-263.

Taşdemir M, Göksu ZL (2001) Some Water Quality Criteria of Asi River (Hatay). E.U. J Fisheries and Aquatic Sci. 18(1-2): 55-64.

Tayhan N (2012) Uzunçayır Baraj Gölünün (Tunceli) Fizikokimyasal Su Kalitesinin Periyodik İzlenmesi. Yüksek Lisans Tezi, Tunceli Üni. Fen Bil. Ens., Tunceli, 79s.

Tepe Y, Mutlu E (2004) Hatay Harbiye Kaynak Suyunun Fizikokimyasal Özellikleri. Dumlupınar Üni., Fen Bil. Ens. Derg. 6: 77-88.

Tepe Y, Mutlu E, Ateş A, Başusta N (2004) Samandağ Karamanlı Göleti (Hatay) Su Kalitesi. Türk Sucul Yaşam Dergisi . 2(3): 408-414. 
Tepe Y, Ateş A, Mutlu E, Töre Y (2006) Hasan Çayı (ErzinHatay) Su Kalitesi Özellikleri ve Aylık Değişimleri. E.Ü. Su Ürünleri Derg. 23 (1/1): 149-154.

Toroğlu E, Toroğlu S, Alaeddinoğlu F (2006) Aksu Çayı'nda (Kahramanmaraş) Akarsu Kirliliği. Coğrafi Bil. Derg. 4 (1): 93-103.

Uslu O, Türkman A (1987) Su Kirliliği ve Kontrolu. T.C. Başbakanlık Çevre Genel Müdürlüğü Yayınları Eğitim Dizisi, 364s.

Uzun S, Uzun A, Yılmaz C, Zeybek Hi (2005) Erfelek Waterfalls, Sinop. 10(14): 331-348. http://edergi.atauni.edu.tr/ataunidcd/article/view/1021006 265/1021005969 (Erişim Tarihi: 22 Temmuz 2018)

Verep B, Serdar O, Turan D, Şahin C (2005) Determination of Water Quality in terms of PhysicoChemical Structure of the River Iyidere (Trabzon). Ecology, 14(57): 26-35.
Vural A, Erkan ME (2006) Diyarbakır Kenti'ndeki Dicle Nehri Balıklarında Mikrobiyolojik Kalite Parametreleri. Dicle Tıp Derg. 33 (3): 153-156.

Ward DR Hackney C (1991) Microbiology of marine food products. Published by Van Nostrand Reinhold, New York, pp 443.

Wu J, Li P, Qian H, Duan Z, Zhang X (2014) Using correlation and multivariate statistical analysis to identify hydrogeochemical processes affecting the majör ion chemistry of waters: a case study in Laoheba phosphorite mine in Sichuan, China. Arabian Journal of Geosciences 7: 3973-82.

Yıldız i (2013) Gelevera Deresi Su Kalitesi ve Kirlilik Düzeyinin Belirlenmesi. Yüksek Lisans Tezi, Giresun Üniversitesi, Fen Bil. Ens., Giresun, 92s. 